\title{
California Bighorn Sheep \\ (OVIS CANADENSIS CALIFORNIANA) \\ Habitat Management
}

by

Lanny 0. Wilson - Editor and Contributor

(Wildlife Biologist, Bureau of Land Management, Idaho) and

Allan Polenz (Wildlife Biologist, Oregon Department of Fish and Wildlife)

Jim Blaisdell (Wildlife Biologist, National Park Service, Oregon)

Alan Sands (Wildlife Biologist, Bureau of Land Management, Idaho)

Walt VanDyke (Wildlife Biologist, Oregon Wildlife Research Unit, U. S. Fish and Wildlife Service)

BLM Library

Denver Federal Center

Bldg. 50, OC-521

P.O. Box 25047

Denver, CO_80225 
vandi.1 M. I

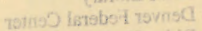
$152-20,02 . \mathrm{ghis}$ phoes zo\& .0: 2550800, tovisod 


\section{TABLE OF CONTENTS}

$\underline{\text { Page }}$

CHAPTER I - CALIFORNIA BIGHORN POPULATION AND HABITAT MANAGEMENT RECOMMENDATIONS

Introduction

Recommendations for California Bighorn

Management

1

Reintroduction and Identification of Suitable Habitat

Determination of Carrying Capacities

Population Data Collection

Predator Control

Livestock Grazing and Wild Horse and

Burro Management

Fencing Practices

E1k and Mule Deer Management

Artificial Salting

Fertilization of Vegetation

Supplemental Feeding

Water Availability

Recreation Use

Road Development

Human Occupancy

Mineral or Fossil Fuel Developments

Hydro-Electric and Associated Developments

Vegetational Manipulation Practices

CHAPTER II - CALIFORNIA BIGHORN DISTRIBUTION, POPULATIONS, GUIDELINES FOR REINTRODUCTION, POPULATION HABITAT INDICATORS, AND MORTALITY FACTORS

General Discussion

Past and Present Distribution 11

Population Decline Factors 11

Present Numbers 11

Guidelines for Reintroduction 11

Population Habitat Indicators $\quad 12$

Minimum Populations $\quad 12$

Population Indices $\quad 13$

Mortality Factors $\quad 14$

Disease and Parasites 14 
。

o

0 


$\begin{array}{lr}\text { Population Habitat Indicators (cont'd) } & \\ \text { Legal and Illegal Hunting } & 15 \\ \text { Predation } & 15 \\ \text { Coyotes } & 16 \\ \text { Cougars } & 16 \\ \text { Eagles } & 17 \\ \text { Wolves } & 17 \\ \text { Other Predators } & 17\end{array}$

CHAPTER III - CALIFORNIA BIGHORN HABITAT REQUIREMENTS 18

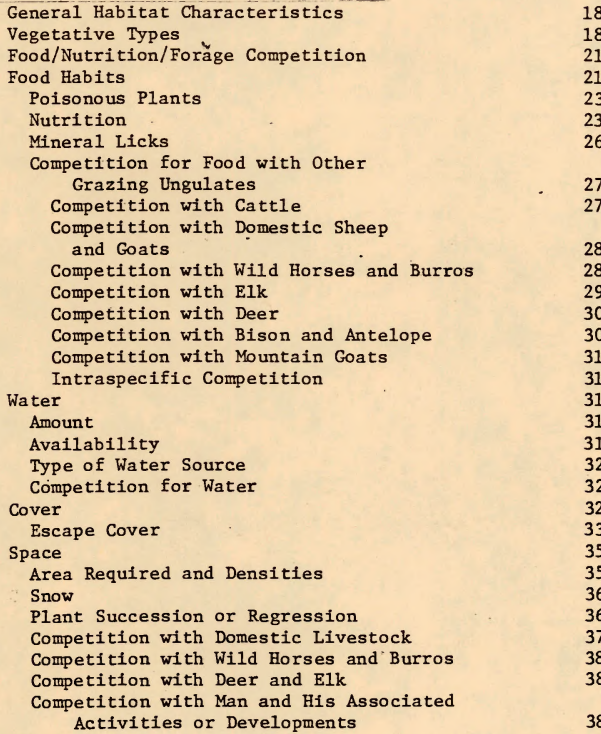


-

○

○ 


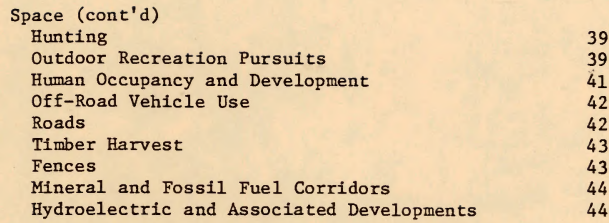

\section{CHAPTER IV - RESPONSE OF CALIFORNIA BIGHORN TO HABITAT MANIPULATION OR ALTERATION PRACTICES}

$\begin{array}{lr}\text { General Discussion } & 46 \\ \text { Mechanical Practices } & 46 \\ \text { Plowing and Planting } & 46 \\ \text { Chaining } & 46 \\ \text { Logging } & 47 \\ \text { Herbicide Treatments } & 47 \\ \text { Fire Management } & 48 \\ \text { Edges and Ecótones } & 48 \\ \text { Livestock Grazing } & 48 \\ \text { Fertilization of Forage } & 49 \\ \text { Supplemental Feeding } & 49 \\ \text { Artificial Salting } & 50 \\ \text { Water Developments } & 51 \\ \text { Snow Accumulation Manipulation } & 52\end{array}$

Literature Cited $\quad 53$

Appendix 1 - Guidelines for Re-establishing and Capturing Desert Bighorn

Appendix 2 - Palatability of Common Plants Found on Existing and Historic California Bighorn Sheep Ranges 
-

○

○ 
CHAPTER I. CALIFORNIA BIGHORN POPULATION AND HABITAT MANAGEMENT RECOMMENDATIONS

\section{Introduction}

The authors recognize that every bighorn habitat and population is different. For this reason, numerous examples are given on various subjects throughout the text in an effort to provide the land manager as much information from different areas of which some may apply to his situation. Hopefully, this effort will result in sound management decisions based on research findings from which this document was prepared. Also, it must be recognized that there is no substitute for common sense when making management decisions based on research findings.

Following the recommendations listed below should result in California bighorn population and habitat enhancement and/or maintenance. Following each recommendation are the subject(s) listed from other chapters in the document which will give the manager the supporting material from which the recomendation was made.

Recommendations for California Bighorn Management

\section{Reintroduction and Identification of Suitable Habitat:}

1. No introductions of other species or subspecies of bighorn should be considered within or adjacent to an existing California bighorn population where cross-breeding could occur. See Chapter II, section: Guidelines for Reintroduction; and Appendix 1.

2. Periodic supplemental transplants of California bighorn from different genetic stocks are encouraged within existing California bighorn populations, particularly in small isolated populations. See Chapter II, sections: Guidelines for Reintroduction, and Population Habitat Indicators (Minimum Populations).

3. Grassland areas or areas which have the potential to be managed in a grassland aspect (particularly bluebunch wheatgrass, Agropyron spicatum; Idaho fescue, Festuca idahoensis; or desert needlegrass, Stipa speciosa) in and adjacent to areas of escape cover within the historic distribution of the California bighorn distribution, as shown on Figure 1, should be considered suitable for California bighorn expansion, maintenance, or enhancement in all land-use planning endeavors. See Chapter II, sections: Past and Present Distribution, and Guidelines for Reintroduction; and Chapter III, sections: Vegetation Types; Food Habits; Nutrition; Cover; and Space (Area Required and Densities; and Plant Succession or Regression). 
○

0

○ 


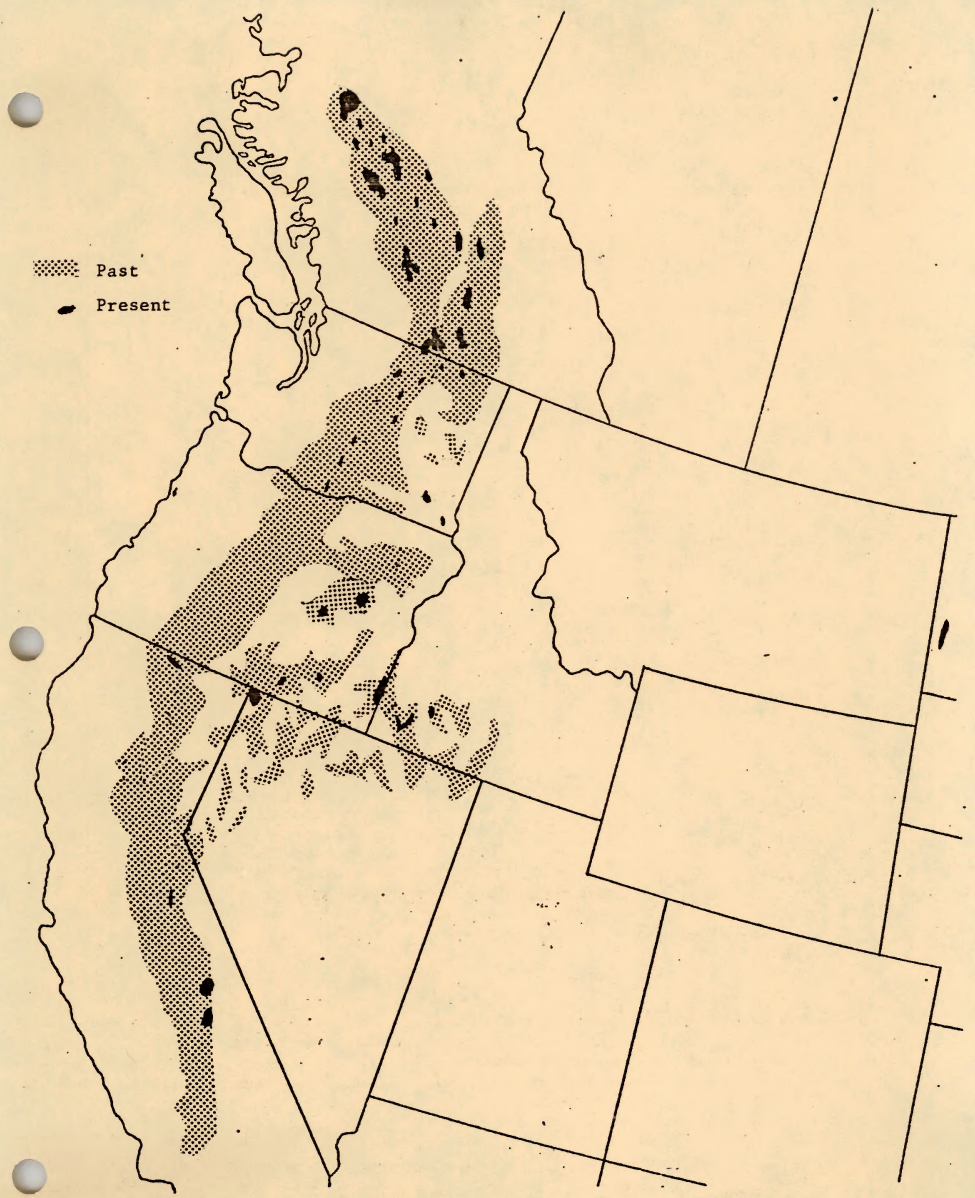

Figure 1. Past and present distribution of the California bighorn of North America 
○

○

○ 
4. For planning and management purposes, flat or rolling areas with good vegetative cover and within two miles of escape cover should be considered an integral part of any California bighorn habitat. See Chapter III, sections: General Habitat Characteristics, Vegetative Types, Food Habits, and Cover (Escape Cover)

5. As a general rule, California bighorn should only be reintroduced into areas which will support a minimum population of 125 animals. See Chapter III, sections: Guidelines for Reintroductions, Minimum Populations, and Space (Area Required and Densities).

Determination of Carrying Capacities:

1. As a general rule, climax bunch grasses such as bluebunch wheatgrass, Idaho fescue, and desert needlegrass should be the key plant species from which range transects and habitat management recommendations should be formulated. See Chapter III, sections: General Habitat Characteristics, Vegetation Types, Food Habits, and Nutrition.

2. To compute range carrying capacities for California bighorn, a figure of 3.9 to 4.0 pounds (air-dry weight) of good quality forage per day per adult bighorn should be used. See Chapter III, sections: Nutrition, and Space (Area Required and Densities)

\section{Population Data Collection:}

1. Lamb-ewe, yearling-ewe, and ram-ewe ratio data are important habitat and population indices and should be collected annually. Only yearling-ewe ratios made from a statistical representative sample of a population made from ground observations should be used. See Chapter III, section: Population Management (Population Indices).

\section{Predator Control:}

1. Predator control for coyotes, bobcats, and/or cougars should be considered where any one or more of the following conditions exist:

a. Prior to and for a minimum of two years following a reintroduction program.

b. During periods of significant population declines when a given bighorn population is at or below the carrying capacity of the range.

c. During periods of high coyote, bobcat, and cougar densities or a combination thereof, where data substantiates significant loss due to predation. See Chapter II, sections: Guidelines for Reintroduction, and Mortality Factors (Coyotes, Cougars, Eagles, Wolves, and Other Predators). 
○

○

○ 


\section{Livestock Grazing and Wild Horse and Burro Management:}

1. No domestic sheep or domestic goats should be permitted to graze within and, if at all possible, adjacent to any occupied California bighorn habitat. See Chapter II, sections: Population Decline Factors, Present Numbers, Mortality Factors (Disease and Parasites); and Chapter III, sections: Competition for Food with Other Grazing Ungulates (Competition with Domestic Sheep and Goats), and Space (Competition with Domestic Livestock).

2. No livestock grazing should be permitted on any California bighorn habitat yearlong ranges or winter ranges for migratory herds at or approaching the bighorn carrying capacity of the habitat. See Chapter II, sections: Population Decline Factors and Present Numbers, Mortality Factors (Disease and Parasites); and Chapter III, sections: Competition for Food with Other Ungulates (Competition with Cattle, Competition with Domestic Sheep and Goats), Space (Snow, Plant Succession or Regression, Competition with Domestic Livestock).

3. Cattle grazing may be acceptable in some California bighorn ranges where the population is far below the range carrying capacity to maintain or increase the nutritive value of grasses or during the late fall to increase use on browse plants to reduce competition between shrubs and grasses under the following conditions:

a. Behavior studies have been conducted, to insure abandonment of the area by bighorn will not occur.

b. The cattle stocking rate is extremely' conservative.

c. No cattle grazing is permitted in or adjacent to lambing grounds during the lambing season.

d. No cattle grazing will occur during the winter on bighorn winter ranges.

See Chapter III, sections: Vegetation Types, Food, Nutrition, Competition for Food with Other Grazing Ungulates :(Competition with Cattle), Escape Cover, Space (Plant Succession and Regression, Competition with Domestic Livestock); and Chapter IV, section: Livestock Grazing).

4. No feral horses or burros should be permitted on any existing or proposed California bighorn range. Existing feral horse or burro populations adjacent to existing or potential California bighorn habitat should be controlled to prevent expansion into the bighorn 
habitat. See Chapter II, section: Guidelines for Reintroduction; and Chapter III, sections: Competition for Food (Competition with Horses and Burros), Water (Competition for Water), Space (Competition with Wild Horses and Burros).

5. Where considered necessary or desirable to exclude domestic livestock trespass or wild horses or burros, water developments should be fenced to encompass an area more than 100 feet square in accordance with the fencing specifications given in the following Fencing recommendation, b. See Chapter III, sections: Competition with Other Grazing Ungulates (Competition with Horses and Burros, Plant Succession and Regression), Water (Competition for Water), Space (Competition with Wild Horses and Burros); and Chapter IV, section: Water Developments.

\section{Fencing Practices:}

1. Fencing within or adjacent to California bighorn ranges should be kept to a minimum, and no woven wire fences of any type or configuration considered. Any fences constructed should meet the following criteria (Helvie, 1971):

a. Three-strand wire fences:

apart.

(1) Posts or stays should be placed not farther than 10 feet

(2) Wires should be spaced 20, 35, and 39 inches above the ground. (If a fourth wire is needed, it should be spaced 43 inches above the ground.)

(3) Under no circumstances should the top two wires be more than four inches apart.

(5) Under no circumstances should the space between the lower two wires be less than 15 inches apart.

b. Three-rail pipe fence:

(1) Posts should be placed not farther than 10 feet apart.

(2) Two-inch diameter steel pipe should be used for rails as rams can easily break wood rails or boards by butting. (If long sections of rall fence are to be built, 4-inch diameter wood poles would probably be satisfactory. 
-

○

- 
(3) the lower edges of rails should be spaced 20,38, and 44 inches above the ground.

See Chapter III, section: Space (Fences).

Elk and Mule Deer Management:

1. No elk should be introduced within or adjacent to any California bighorn habitat and where elk do occur they should be maintained in minimal numbers. See Chapter II, section: Guidelines for Reintroduction; and Chapter III, sections: Water (Competition for Water), Competition with Other Grazing Ungulates (Competition with Elk), Space (Competition with Deer and Elk).

2. Mule deer populations should be maintained at minimum levels on all California bighorn ranges. See Chapter II, section: Guidelines for Reintroduction; and Chapter III, sections: Water (Competition for Water), Competition with Other Grazing Ungulates (Competition with Deer), Space (Competition with Deer and Elk).

\section{Artificial Salting:}

1. Supplemental minerals, protein, and/or medication (salting) should be provided in any California bighorn range where a mineral(s) and/or protein deficiency(s) has been documented. Salting should be done in such a manner where:

a. Salting will not result in attracting livestock, wild horses or burros into the bighorn habitat.

b. Salting will not result in concentrating deer and/or elk or any other grazing ungulates within the bighorn habitat.

c. The mineral and/or protein supplement will be used by the bighorn. Sodium or phosphorus appear to be the two most important minerals sought by bighorn.

d. Research findings justify the use of salt as a medium of providing medication to bighorn to combat a disease and/or a parasite problem.

See Chapter II, section: Mortality Factors (Disease and Parasites); Chapter III, sections: Nutrition, Mineral Licks, Space (Competition with Domestic Livestock, Competition with Wild Horses and Burros, Competition with Deer and Elk, Plant Succession or Regression); and Chapter IV, section: Artificial Salting. 
○

0

○ 


\section{Fertilization of Vegetation:}

1. Fertilization of native vegetation should only be considered following plot evaluation studies within the area under consideration to be fertilized. See Chapter III, sections: Nutrition, Food Habits (Poisonous Plants); and Chapter IV, section: Fertilization of Forage.

\section{Supplemental Feeding:}

1. Supplemental feeding should only be considered where the rangecarrying capacity is not being exceeded and where one or more of the following conditions exist:

a. Medication to combat a disease and/or parasite problem can be mixed with the food supplements.

b. For trapping and transplating purposes.

c. To insure adequate nutrition where protein, mineral, or other nutritional requirements are lacking.

d. Loss of a critical area(s) due to some catastrophic impact to the habitat such as a large wildfire until the habitat recovers. See Chapter II, sections: Guidelines for Reintroduction, Population Management (Disease and Parasites); Chapter III, sections: Vegetation Types, Food Habits, Nutrition, Mineral Licks; and Chapter IV, sections: Supplemental Feeding, Artificial Salting.

\section{Water Availability:}

1. Water should be available in sufficient quality and quantity in areas where vision is not obstructed and adjacent to escape cover not to exceed $3 \frac{1}{2}$ miles between sources. Water available at one-mile increments is considered optimum. See Chapter III, sections: Water (Amount, Availability, Type of Source); and Chapter IV, section:

Water Developments.

\section{Recreation Use:}

1. Recreational use (backpacking, picnicking, camping, hunting, fishing, cross-country skiing, etc.) should be closely regulated, and no such uses permitted within or adjacent to any critical areas during critical periods (lambing grounds in the spring, winter ranges, waterholes during periods of drought, periods of snow cover, and cold). See Chapter II, section: Guidelines for Reintroduction; and Chapter III, sections: Space (Snow, Outdoor Recreational Pursuits, Roads, Hydro-electric and Associated Developments). 
○

0

0 
2. Camping should not be permitted within sight of any California bighorn watering site or in the immediate vicinity of any high bighorn use area (Trefethen, 1975; Mexican and Desert Bighorn section). See Chapter II, section: Guidelines for Reintroduction; and Chapter III, sections: Water (Availability), Space (Outdoor Recreational Pursuits, off-Road Vehicles).

3. No off-road vehicles should be permitted off designated roads or trails on California bighorn yearlong ranges, and only in designated areas during specified seasons in migratory bighorn habitats. See Chapter III, section: Space (Off-Road Vehicle Use, Roads).

\section{Road Development:}

1. Road development should be avoided, and, where feasible, existing roads closed in any existing or potential California bighorn habitats. See Chapter III, section: Space (Off-Road Vehicle Use, Roads, Timber Harvest).

\section{Human Occupancy:}

1. No permanent human occupancy developments should be permitted within or, if at all possible, adjacent to California bighorn sheep ranges. See Chapter II, sections: Space (Competition with Domestic Livestock, Competition with Man and His Associated Activities or Developments, Outdoor Recreation Pursuits, Human Occupancy and Development, Off-Road Vehicle Use, Roads).

\section{Mineral or Fossil Fuel Developments:}

1. No mineral or fossil fuel developments should be considered in any California bighorn habitat unless assurance via stipulations or cooperative agreements can be initiated which will insure:

a. No impact on any critical area (lambing grounds, winter range, important summer range use area, watering locations) will occur.

b. Minimum disturbance during the exploration or development processes, particularly during the lambing season and periods of stress (drought periods during the summer and periods of snow and extreme cold).

c. Minimum road development and road closure following exploration.

d. Suitable revegetation can be achieved in disturbed areas.

e. No permanent human occupancy structures will be developed. See Chapter III, sections: Water (Type of Source), Space (Snow, Competition with Man, His Associated Activities and Developments, Human Occupancy 
○

○

○ 
and Development, off-Road Vehicle Use, Roads); and Chapter IV, section: Mechanical Practices (Plowing and Planting).

Hydro-Electric and Associated Developments:

1. No hydro-electric or associated developments (concrete ditches, canals, etc.) should be considered in California bighorn habitat that would flood or adversely impact a significant portion of the total habitat or critical area (See Mineral or Fossil Fuel Developments Recommendation (a) for critical areas.) See Chapter III, section: Hydro-electric and Associated Developments.

2. No hydro-electric development should be considered in or adjacent to California bighorn yearlong or critical areas unless assurance via stipulations or cooperative agreements can be guaranteed that associated human activities (boating, picnicking, fishing, water skiing, swimming, etc.) can be closely regulated. See Chapter III, sections: Space (Competition with Man and His Associated Activities and Developments, Outdoor Recreation Pursuits, Human Occupancy and Developments, Hydro-electric and Associated Developments).

\section{Vegetational Manipulation Practices:}

1. No habitat manipulation practices (plowing and planting, chaining or logging) should be undertaken during critical periods (see Mineral or Fossil Fuel Developments recommendation (b) for critical periods) in any California bighorn habitat. See Chapter III, sections: Space (Competition with Man and His Associated Activities and Developments, Outdoor Recreation Pursuits, Off-road Vehicle Use, Timber Harvest).

2. Mechanical manipulation practices should only be considered in California bighorn habitats in areas of less than $30 \%$ slopes, and in areas of fine textured soils where precipitation generally comes in the form of snow and gentle rain. See Chapter IV, sections: Mechanical Practices (Plowing and Planting, Chaining and Logging).

3. Timber harvest should not be permitted in any California bighorn habitat except as a habitat management tool and only in areas where associated road construction can be minimized and roads closed to public use following logging operations. See Chapter III, sections: Space (Off-Road Vehicle Use, Roads, Timber Harvest; and Chapter IV, sections: Logging and Snow Accumulation Manipulation).

4. Timber harvest should be permitted in California bighorn ranges where bighorn habitat can be expanded or enhanced via helicopter logging or selected clear cuts, where road access into the timber harvest areas can be closed following logging. See Chapter III, sections: Vegetative Types, Space (Plant Succession or Regression, Off-Road Vehicle Use, Roads, Timber Harvest; and Chapter IV, sections; Mechanical Practices (Logging), Edges and Ecotones, Snow Accumulation Manipulation. 
0

0

0 
5. Plowing and chaining in areas less than $30 \%$ slopes and in areas of fine textured soils in which dense stands of trees and shrubs have invaded should be rehabilitated to grasses and forbs (native species being the most desirable) to enhance California bighorn habitat or to expand their range. See Chapter III, sections: Vegetative Types, Space (Plant Succession or Regression); and Chapter IV, sections: Mechanical Practices (Plowing and Seeding, and Chaining).

6. Palatable native browse species should be established in low densities in any plowing and seeding, chaining or logging where such browse species are known to be an important forage plant for a specific California bighorn population. See Chapter. III, sections: Food Habits, Nutrition; and Chapter IV, sections: Mechanical Practices (Plowing and Planting, Chaining, Logging), Edges and Ecotones.

7. Where the desired vegetative responses can be achieved, periodic, prescribed, spring, controlled burning (not to exceed $20 \%$ of the total bighorn sheep habitat at any one given time) should be implemented on most California bighorn habitats, particularly those habitats susceptible to invasion by dense stands of undesirable trees or shrubs. See Chapter III, sections: General Habitat Characteristics, Vegetative Structure, Food Habits, Nutrition, Space (Plant Succession or Regression); and Chapter IV, sections: Fire Management, Edges and Ecotones.

8. Following feasibility studies which document that desired habitat responses can be achieved and in areas where fire management methods are not feasible, herbicide treatment can be employed in areas of California bighorn habitat which have been invaded by undesirable shrubs or to increase grass production. If possible, dead brush should not be left standing on treated areas. See Chapter III, sections: General Habitat Characteristics, Vegetative Structure, Food Habits, Nutrition, Spaee (Plant Regression or Succession); and Chapter IV, sections: Herbicide Treatments, Edges and Ecotones). 
o

○

- 
CHAPTER II. CALIFORNIA BIGHORN DISTRIBUTION, POPULATIONS, GUIDELINES FOR REINTRODUCTION, POPULATION HABITAT INDICATORS, AND MORTALITY FACTORS.

\section{General Discussion:}

Literature available on California bighorn sheep (Ovis canadensis californiana) is limited. Other subspecies of bighorn, particularly Rocky Mountain bighorn (ㅇ. $\underline{\text { c. }}$ canadensis) and Nelson's bighorn (ㅇ. $\underline{c}$. nelsoni) occupy habitats similar to areas occupied or historically inhabited by California bighorns (i.e., vegetation types, forage species, physiography). Consequently, publications on bighorn populations believed to be pertinent to California bighorn habitat management and protection were utilized regardless of subspecies.

Past and Present Distribution:

Figure 1 (see page 2) depicts the past distribution of California bighorn sheep in North America based on literature reviews (Cowan, 1940; and Buechner, 1960) and the authors' knowledge of the species. The present populations, many of which are recent introductions, are also depicted on Figure 1.

Population Decline Factors:

Figure 1 indicates that less than $10 \%$ of the historic California bighorn habitat is occupied to date. Cowan (1940) and Buechner (1960) both concurred that the introduction of disease and parasites, particularly scabies mites, associated with domestic sheep were responsible for the major decline in bighorn numbers in North America. Other contributing factors were competition for food and space with domestic livestock, indiscriminate hunting, and human encroachment.

Present Numbers:

The current total population of California bighorn in North America is between 3,450 to 3,600 (Trefethen, 1975) of which 1,650 to 1,700 are estimated to occur in the United States. The remaining California bighorn outside the United States all occur in south-central British Columbia, Canada.

\section{Guidelines for Reintroduction:}

Bighorn sheep are generally not successful dispersers and colonizers into new habitats in comparison to deer and mosse (Geist, 1971). Therefore, the chances of bighorn reoccupying historic habitats from which they have been eliminated could take several decades. Coupled 
0

○

0 
with the man-made barriers of today--highways, cities, towns, fences, etc.--the probability of bighorn naturally reoccupying historic ranges is extremely remote.

The California bighorn was classified as a "rare" species under the classification system via the Rare and Endangered Species Act of 1969. Such a classification connotates the limited numbers and distribution. As depicted in Figure 1, this situation has changed little today even though the species was dropped from the "threatened" species list via the Endangered Species Act of 1973.

Because of their natural and unnatural limitations to reoccupy historic bighorn ranges, and because their numbers are very limited, land managers, particularly public land managers, are encouraged to identify, maintain, and/or enhance areas suitable for California bighorn re-establishment.

Criteria for determining suitability of historic bighorn habitats for reintroduction and techniques for capturing and re-establishing bighorn populations are given in Appendix 1. This technical paper, "Guidelines for Re-establishing and Capturing Desert Bighorn" is distributed by the Desert Bighorn Council based on the approval of the Desert Bighorn Council's Technical Staff and was reprinted in the publication, "Wild Sheep of Modern North America."

California bighorn (ㅇ. c․ californiana) and Rocky Mountain bighorn (o. c. canadensis) or any other subspecies of bighorn should never be introduced into or adjacent to the same area. The various species and subspecies of bighorn recognized in North America have evolved with genetic characteristics unique to each species and subspecies. Loss of distinct gene pools could result in loss of genetic traits needed for adaptation and occupation of some historic bighorn ranges.

\section{Population Habitat Indicators:}

The following discussion is not intended to provide guidance or data on management of bighorn populations. Management of bighorn populations on most Federal lands is the primary responsibility of the State wildife agencies. The following discussion pertains to interpretation of population data as such data reflect habitat or population health.

Minimum Populations: Many existing populations of California bighorn contain less than 100 individuals (Spalding and Mitche11, 1970). Geist (1974) suggests that enough space be available for about 125 bighorn when transplanting is contemplated. This recommendation probably stems from a concern also expressed by Wilson (1974) over in-breeding problems 
。

○

○ 
which could result in small isolated populations; however, conclusive evidence is lacking. Two small populations in the Sierra Nevada Range, California, containing 15 and 25 bighorn sheep in 1949 are now believed to be extinct (Weaver, 1972).

In-breeding problems can be avoided, and populations consisting of 50 or more animals can be sustained if the habitat is suitable and the populations are located within a few miles of other populations and there are no barriers to impede movements. Small populations can. artificially be maintained with periodic supplemental transplants. Supplemental transplants have proven effective in several Colorado populations. Improved reproductive vigor and good population growth were correlated from supplemental transplants over a 10-15 year period (Rutherford, 1972).

Population Indices: Lamb-ewe ratios immediately following the lambing season reflect reproductive success. With few exceptions, reproductive success is directly related to habitat quality. As a general rule, lamb-ewe ratios less than 30 lambs per 100 ewes is low; 30-50 lambs per 100 ewes is average; and over 50 lambs per 100 ewes is high. Factors by themselves or in combination which can result in low lamb-ewe ratios are poor range conditions, competition for food or space with other grazing ungulates, frequent human disturbance, harassment during the late winter or early spring, lack of suitable lambing areas, a severe climatic event, predation, disturbance during the lambing season, mineral deficiencies, and disease or parasites.

The mortality rate in bighorn sheep is usually greatest during the first year of 1ife (Murie, 1944; and Hansen, 1967). Therefore, yearlingewe ratios taken immediately following the lambing season can be an important indication to population and habitat quality. Significant changes between lamb-ewe ratios and yearling-ewe ratios for the same year class can be á good indicator of problems. For example, if the lamb-ewe ratio was 60 lambs per 100 ewes in 1976 and 20 yearlings per 100 ewes in 1977, severe mortality of this year class occurred. As a general rule, less than 20 yearlings per 100 ewes is low; 20 to 40 yearlings per 100 ewes is average; and over 40 yearlings per 100 ewes is high. Population trend counts must also be taken into consideration when using lamb-ewe, yearling-ewe ratios. A good ratio can result from poor yearling survival coupled with an even worse ewe survival. This situation can be identified based on comparisons of past trend counts and one's personal knowledge of climatic or other factor $s$ which could account for a sudden population decrease. Factors by themselves or in combination which can result in low yearling-ewe ratios are the same as listed for lambs except for disturbance during the lambing season and lack of suitable lambing areas. 
o

0

○ 
Care must be taken when using yearling-ewe data. Yearling rams and in some cases yearling ewes are difficult to distinguish from adult ewes, especially when observed from aircraft. Therefore, only statistical representative samples of a population made from ground observations should be used. Also, yearling rams have been observed in mature ram groups (Van Dyke, personal communication). Thus, a random inventory of all age and sex classes of a population is required.

Ram-ewe ratios are a good indication of hunting pressure and/or success. The greater the variance in hunted populations from 100 rams to 100 ewes, the greater the hunter pressure or sex specific mortality. Ram-ewe ratios can also be a good indicator in populations in which excessive illegal hunting is taking place.

Mortality Factors: As discussed above, when analyzing lamb-ewe or yearling-ewe ratios, disease and parasites, illegal hunting, and predation are factors that must be analyzed if low ratios are encountered or a population is declining. Also, knowledge of these factors is necessary when considering other uses of lands in or adjacent to Calffornia bighorn populations.

Disease and Parasites: The greatest threats of disease and parasites to bighorn are those transmitted from domestic sheep and, to a lesser degree, from cattle. Scabies mites of the genus Psoroptes and lungworm of the genus Protostrongylus are of major importance. The scabies mites generally infect the ears which can lead to blockage of the ear passage, causing deafness (Irvine, 1969; and Morgan, 1971) and .... heavy infestations leads to loss of hair, particularly around the ears, face, and belly, with open sores or lesions. A bighorn in this condition is vulnerable to pneumonia and other infections.

Heavy infestations of lungworm lead to pneumonia. Rough coats, coughing, shortness of breath are indicators of lungworm burdens.

Other significant disease and/or parasites transferred from domestic livestock, particularly domestic sheep, for which drastic bighorn population declines̀ have been documented are "feedlot" disease, resulting from infections of coccidia of the genus Eimeria (Jones and Bear, 1973) and blue tongue (Hailey et al. 1972, and Blaisdell, 1975). Blue tongue is a virus which is usually transmitted by gnats of the genus Culicoides. Blue tongue results in weakening the animals, making them susceptible to pneumonia. Symptoms are the same as the lungworm-pneumonia complex noted above. Ecthyma (sore mouth disease) was reported in Oregon by Blaisdell (1976). 
-

○

○ 
Other parasites and diseases harbored il by livestock which can lead to infections of bighorn and have the potential to be dangerous are round worms, tape worms, bacterial and virus infections. Smith (1954:27) states, "It should be stressed, however, that so-called 'epidemics' of ten have many contributory factors, including prolonged adverse weather, malnutrition, and over-crowded range conditions. Normally healthy sheep are commonly infected with both internal and external parasites without noticeable harm." Wilson (1968) suggests that mineral deficiencies can result in a greater incidence of parasite or disease infections.

Legal and Illegal Hunting: Legal hunting poses no threat to bighorn sheep populations if hunts are conservative. However, illegal hunting ("poaching") can be significant.

Weaver (1972) reported that deer hunters occasionally kill bighorn sheep in California. There is no legal hunting of bighorn in California.

Jones et al. (1957) believed that illegal hunting constituted a drain on the bighorn sheep in the Santa Rosa Mountains of California.

Sugden (1961) stated that poaching was a factor on bighorn populations in British Columbia, Canada, the degree of which was unknown. He also stated that as outdoor recreation use increases, illegal killing of bighorn could become a serious problem.

Poaching has recently become a major concern. For example, two California bighorn rams were shot in a paddock in Lava Beds National Monument in 1973 (Blaisdell, 1974). All work groups who comprised the nucleus of the bighorn sheep experts in North America recommended techniques and methods to reduce illegal hunting (Trefethen, 1975). The emphasis given to trophy hunting of large rams and the "grand slam" has greatly accelerated illegal hunting of bighorn. The "grand slam" is a status term and selective club given to those hunters who have harvested a Dall, Stone, Rocky Mountain, and desert bighorn. Limited huntable populations and hunting permits for bighorn have resulted in the California bighorn being one of the prized species of big game in the world.

Predation: Several predators are capable of killing bighorn sheep. These include: coyotes (Canis latrans); wolves (Canis lupus); cougars (Felis concolor) bobcats (Lynx rufus); bears (Ursus americanus); golden eagles (Aquila chrysaetos); and bald eagles (Haliaeetus leucocephalus). 
-

○

○ 
The tendency of bighorns to inhabit rugged, precipitous terrain makes them less susceptible to predation than many other game species. Buechner (1960:112) stated that the vulnerability of bighorn to predation while on cliffs was very low, but their vulnerability would increase as sheep moved farther from the safety of cliffs and rough terrain (escape cover).

Coyotes: Buechner (1960), Murie (1944), Smith (1954), Weaver (1972), Welles and Welles (1961), Sugden (1961), and Morgan (1968) indicated that the effect of coyotes as predators on bighorn was insignificant. Note that these studies were made during the era of maximum predator control which is not the case today.

Stelfox (1976) reported coyotes to take small numbers of sheep in the National Parks of western Canada.

Drewek (1970), in southeastern Idaho, witnessed a coyote attack on a group of mature rams without success. Blaisdell (personal communication, 1977) observed bighorn ignoring coyotes, and others have observed bighorn chasing .coyotes.

Wilson (1967) found bighorn sheep parts in coyote and bobcat scats occurred in $9.1 \%$ of the 110 scats sampled. This was during a period of high coyote densities. The incidence of animal remains in scats only determines what an animal has been eating. There was no data to show the coyotes or bobcats had killed the bighorns; however, Wilson believes some lambs were definitely killed by coyotes, the degree of which was unknown.

Cougars: Weaver (1972) stated that the cougar was the most capable predator of bighorn sheep. He found no indication of cougar predation of bighorns in the Sierra Nevadas.

Stelfox (1976) reported cougars to take a small number of sheep in the National Parks of western Canada.

Cougars can be serious predators of bighorn where bighorn are placed in large inclosures (Cooper, 1973; Kilpatrick, 1975). This may indicate that cougars are a greater threat than is currently recognized.

Sugden (1969) in British Columbia believes that cougars had only a minor effect on bighorn sheep populations. He noted that presence of cougar populations in an area was probably related to abundance of another prey species, such as deer, with sheep kills being only incidental.

Smith (1954) in Idaho felt that cougars could be effective predators on bighorns. However, unless cougar populations reach a high level, the loss of bighorn to this predator will probably be minimal. 
-

○

- 
Eagles: Weaver (1972) in the Sierra Nevadas, Welles and Welles (1961) in Death Valley, Sugden (1961) in British Columbia, and Drewek (1970) and Morgan (1968) in Idaho reported golden eagles to be present over bighorn ranges, but they did not observe any incidents of predation. Buechner (1960) noted that eagles have been known on occasion to take bighorn lambs, but eagle predation is probably insignificant. Stelfox (1976) did not report any sheep losses to either the golden eagle or the bald eagle, but they were sighted harassing sheep.

Eagles do not appear to be a serious threat to bighorn.

Wolves: Few accounts of wolves preying on sheep were found. Murie (1) s44) studying Dall sheep (Ovis dalli dalli) in Alaska believes that the wolves tended to keep sheep populations in check.

Stelfox (1976) cited a wolf study in Jasper National Park where minimal amounts of sheep hair occured in wolf scats.

Sugden (1961) felt that wolf predation on California bighorns in British Columbia was insignificant.

The essential absence of wolves in California bighorn habitats in the U. S. makes the question of wolf predation on California bighorn academic.

Other Predators: Smith (1954) in Idaho, and Sugden (1961) in British Columbia stated that bobcats and bears were capable predators of bighorn sheep. They believe they were not serious threats to bighom populations in their studies.

In view of the above discussion, two points for California bighorn management must be considered:

1. Predation may be negligible on a good-size established population, but it could effect a small population. Reintroductions could be particularly vulnerable (Wilson et al. 1973).

2. Esthetics and nonconsumptive use of wildlife are becoming more significant to the general public. Therefore, a manager may choose to lose bighorns to predators so that these latter species are also present for public enjoyment. 
o

○

○ 
CHAPTER III. CALIFORNIA BIGHORN HABITAT REQUIREMENTS.

General Habitat Characteristics:

Every wildlife species has special physiological adaptations for surviving in specific environments. In the case of California bighorn, the ability to live in environments where extremes in temperature ranges occur (from below zero ${ }^{\circ} \mathrm{F}$ in the winter to over $100^{\circ} \mathrm{F}$ in the summer), sight. and the capability to negotiate extremely hazardous terrain (escape cover) are distinctive attributes.

California bighorn inhabit mountains, canyons, or combinations of both habitats. Such areas dominated by low-growing vegetation provide optimum vegetative structure. Areas of tall, dense vegetation such as mountain shrublands and forests generally are avoided, although some populations maintain traditional migration routes through such areas (Sugden, 1961; Geist, 1971). Rocky Mountain bighorn have been observed bedding in dense timbered areas in the summer and late fall during the day in Idaho and Wyoming (Wilson, 1977, personal communication). California bighorn have been observed in California and British Columbia in timber on north exposures during the sumer where temperatures are generally cooler and green vegetation persists for longer periods compared to southern exposures (Wilson, 1977, personal communication). The ability to see great distances to detect dangers in and/or adjacent to escape cover seems to be habitat characteristic common in all California bighorn habitats.

\section{Vegetation Types:}

Vegetative communities found on existing and historic California bighorn ranges were organized into six broad vegetation zones after Franklin and Dyrness (1973): (1) desert shrub; (2) shrub/grass (shrub Steppe); (3) grassland (Steppe); (4) Juniper (Savanna); (5) coniferous forest; and (6) alpine-subalpine. These zones describe the potential or climax vegetation. Consequently, not only are the structural characteristics and species composition different between zones, but each zone may have seral stages where structure and/or species are very different from climax. The relative value of each vegetation zone and its seral stages to California bighorn is discussed in the following pages.

1. Desert shrub vegetation types provide fair-to-poor bighorn habitat. The low-growing (shadscale, Atriplex confertifolia) or widely spaced dominant shrubs (greasewood, Sarcobatus vermiculatus) provide "open" habitat for California bighorn. However, the harsh environment and poor soils characteristically associated with shadscale and greasewood result in low plant productivity. Conditions are even poorer for bighorns in areas where the naturally limited perennial bunchgrasses 
○

○

○ 
such as squirreltail (Sitanion spp) and Indian ricegrass (Oryzopsis hymenoides) have been eliminated by heaving grazing (successionally regressed).

2. Shrub/grass vegetation types provide excellent-to-poor bighorn habitat. Generally, the higher and more dense the shrubs, the poorer the habitat (Figure 2). Height influences the "openness" while density influences the production of the preferred forage plants (usually grasses). Advanced successional stages have relatively lower proportions of shrubs and higher proportions of preferred perennial bunchgreases and forbs (Franklin and Dyrness, 1973). Consequently, the more advanced successional stages provide the best bighorn habitat.

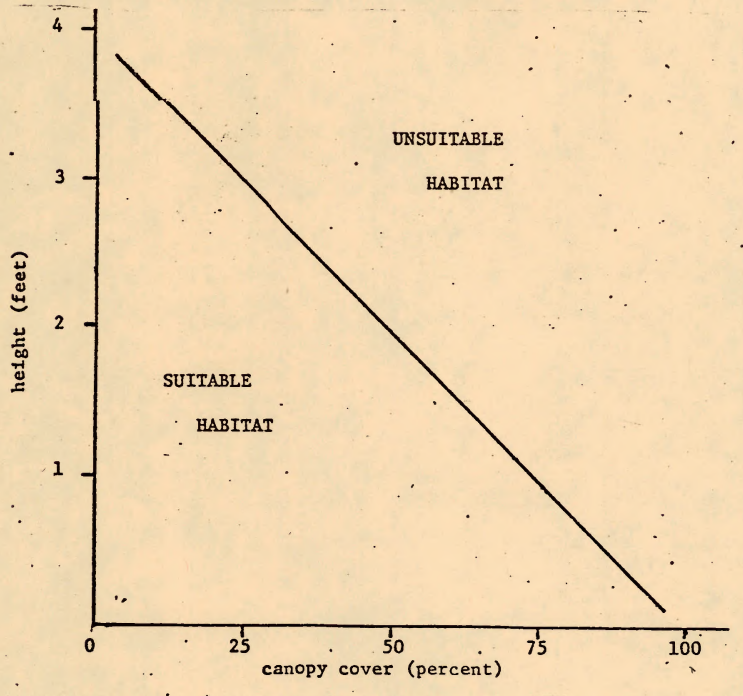

Figure 2. Theoretical habitat suitability for bighorn sheep based on plant height and canopy coverage of shrubs. 
o

○

○ 
Shrub/grass vegetation types include a large variety of shrubdominated communities which are widespread over much of the existing and historic range of California bighorns. Most of these vegetation types are dominated by a species of sagebrush (Artemisia spp.) although, occasionally, bitterbrush (Purshia spp.) and mountain mahogany (Cercocarpus spp.) are the dominant vegetative types (Franklin and Dyrness, 1973).

3. Grasslands provide optimum vegetative structure for bighorns. Advanced successional stages consisting of several species of perennial bunchgrass and perennial forbs with occasional shurbs provide excellent forage. The loss of or a significant reduction of climax dominants results in poorer quality habitat. Severe regression to an annual stage could reduce the carrying capacity to a level where the population could not persist.

4. The Juniper (Juniperus spp.) zone offers good-to-poor bighorn habitat. Tree-dominated advanced successional stages are used little by bighorn, probably because of the reduced "openness" and the lack of understory vegetation. Mid-successional stages consisting of scattered trees with perennial bunchgrasses and forbs provide good habitat. Bighorns are known to make intensive use of pinyon-juniper woodlands "opened" by fire (Graf, 1971). Early seral stages where the perennial bunchgrasses have been largely eliminated due to heavy livestock grazing and frequent fires provide poor bighorn habitat.

5. Coniferous forests provide good-to-poor bighorn habitat, depending upon the density of trees and the structural characteristics of the understory. Widely scattered trees with a herbaceous understory, such as an "open" ponderosa pine (Pinus ponderosa) vegetative type, provides good habitat. Conversely, a closed canopy spruce-fir forest provides poor habitat. Nevertheless, the early successional stages of a spruce (Pseudotsuga menziesii) and fir (Abies spp.) forest may provide good temporary habitat for bighorns.

6. Alpine/subalpine vegetation (includes mountain meadows) provides excellent-to-good bighom habitat. The vegetation in general is low in structure with high plant species diversity. Advanced successional stages in the interior mountains are dominated by a dense vegetative coverage of grasses. Heavy grazing causes deterioration to a grassforb stage with a high proportion of bare areas.

Areas in excellent condition provide abundant, nutritious forage, but use by bighorn is limited to the summer season. The highest densities of California bighorns are found in British Columbia, Canada, where they summer on alpine/subalpine ranges and winter on perennial grassland ranges. 
○

○

○ 
The annual and biennial seral stages of all vegetation types provide poor bighorn habitat. The structure is optimum, but the amount of forage produced can fluctuage greatly from year to year and is of low nutritive value for most of the year.

Fire is an important factor in all the vegetation types, except the desert shrub type. It influences vegetation structure and species composition. Several dominant plants are fire sensitive (sagebrush and juniper) and reoccupy burned sites by reinvasion rather than by sprouting. On the other hand, perennial bunchgrass-like bluebunch wheatgrass and Idaho fescue are relatively insensitive to fire (Franklin and Dyrness, 1973). Other plants. such as bitterbrush will sometimes resprout, depending upon the intensity of the fire. Consequently, fire can create high quality bighorn habitat. However, too frequent occurrence of fire in these same areas can cause severe successional regression resulting in a plant conmunity dominated by annuals such as cheatgrass (Bromus tectorum) or medusa (Taeniatherum spp.).

Heavy grazing, like fire, tends to cause successional regression. However, unlike fire, the plants most beneficial to bighorns are sensitive to being overgrazed. Continuous heavy grazing applies selective pressure which favors unpalatable plants and leads to the invasion of annuals.

\section{Food/Nutrition/Forage Competition:}

\section{Food Habits:}

In general, grasses and forbs are the major staple diet of California bighorn. Thrifty California bighorn populations always occur in areas providing quality forage and, generally, quality forage occurs in moderately-deep to deep residual soils which occur on gently rolling slopes and alluvial plains and valleys. Flat to rolling topography adjacent (up to two miles in some cases) to escape terrain are often overlooked as critical bighorn use areas by many land-use planners, as many planners only associate bighorn with rough, precipitous terrain. Failure to recognize or identify such areas may be the reason that many bighorn populations never realize their maximum population growth. This subject is discussed in more detail in the sections dealing with cover and competition for food.

Grasses are considered a staple forage during all seasons, particularly spring and summer. Browse consumption increases during the fall and may become an important part of the winter diet in many habitats. Forb consumption is usually greatest during the spring and summer (Todd, 1972). Dunaway's (1972) summary of food habits from 15 different bighorn ranges provides a quantitative picture of the seasonal and yearlong use of these forage classes (Figure 3 ). 
○

○

- 

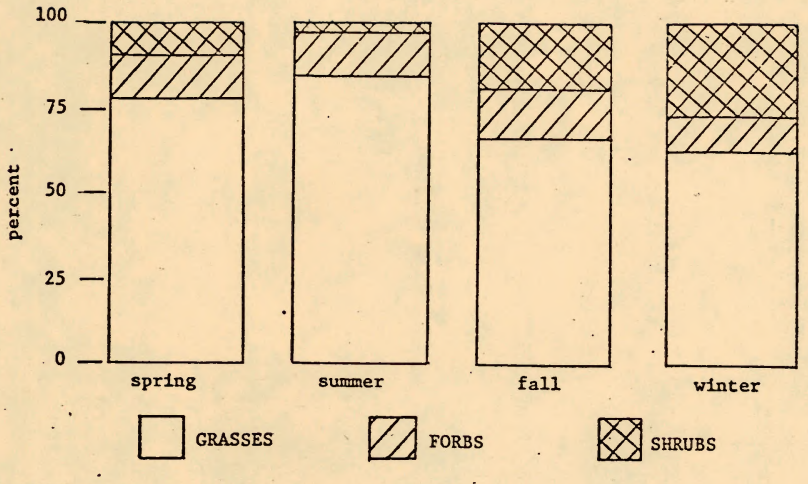

FORBS

Figure 3. Seasonal food habits of North American bighorn sheep; average from 15 bighorn ranges (source: Dunaway 1972).

Yoakum 1964, 1966) investigated forage class preferences for desert bighorns in southern Nevada by comparing range composition to dietary composition. He found that grasses were preferred, although his 1964 data indicated an even higher preference for forbs. Data presented by Blood (1967) indicate that the dietary composition of grasses used by California bighorns in southern British Columbia exceeded the range composition, although the bighorns oceupied grass dominated vegetation types.

Where the distribution of bighorn sheep and bluebunch wheatgrass coincide, bluebunch wheatgrass is consistently noted as the primary forage (Smith, 1954; Sugden, 1961; Blood, 1967; Berwick, 1968; Drewek, 1970; 0ldemeyer et al., 1971). This single species may contribute up to $40 \%$ of the diet (Blood, 1967). Desert needlegrass is the primary grass utilized by California bighorns on the winter ranges of the Sierra Nevadas (McCullough and Schneegas, 1966; Dunaway, 1972). Sandberg bluegrass (Poa sandbergii), Idaho fescue, Indian ricegrass, and squirreltail are other important forage grasses (Todd, 1972). Drewek (1970) observed frequent use of Great Basin wildrye (E1ymus cinerous) throughout the year by a transplanted population of California bighorn in Idaho. Cheatgrass is frequently found in the late winter and early spring diet (Smith, 1954; Blood, 1961; Wilson, 1968; Dunaway, 1972). 
0

0

。 
of all available winter forage species, bitterbrush was the most used by California bighorns in the Sierra Nevadas (McCullough and Schneegas, 1966; Dunaway, 1972). Other browse frequently noted in the diet are curlleaf mountain mahogany (Cercocarpus ledifolius), bitterbrush, serviceberry (Amelanchier alnifolia), Nevada ephedra (Ephedra nevadensis), willow (Salix spp,),buckwheat (Eriogonum spp.), and shrubby cinquefoil (Potentilla fruticosa) (Todd, 1972). Lauer and Peek (1976) found Wyoming big sagebrush (Artemisia tridentata wyomingensis) was used little by bighorn sheep, but mountain big sagebrush (A.t. vaseyana) was used moderately. Many food habit studies indicate that green and gray rabbitbrush (Chrysothamus viscidiflorus and $\underline{C}$. nauseosus) are frequently used in minor amounts during the winter.

Smith (1954) and Blood (1961) observed that arrowleaf balsamroot (Balsamorhiza sagittata) was heavily utilized during the early growth stage. Lupine (Lupinus spp.) was favored during the winter (Oldemeyer et al., 1971), particularly the seed pods (Blood, 1967). Lauer and Peek (1976) found biscuitroot (Lomatium SpP.) to be an important late winter and spring forage.

A list of common plants occurring on existing and historic California bighorn ranges and their relative palatability is given in Appendix 2 . Palatability was estimated from the frequency of reported instances of use and the relative quantities used. For those plants which have not been reported for bighorn, palatability was estimated based on palatability ratings to domestic grazing animals.

Poisonous Plants: Deming (1964) and Irvine (1969) believe that poisonous plants pose little or no problem to bighorn populations. Deming noted an instance or two where plant poisoning was suspected in sheep mortality, but this was not positively confirmed. Blood (1967) observed bighorns eating death camas (Zygadenus spp.) and lupine with no apparent ill effects.

Nutrition: The nutritional requirements of bighorns are one of the least known aspects of their ecology. Chemical analysis of some important bighorn forages has been conducted (Honess and Frost, 1942; Blaisdell et al, 1952; McCullough and Schneegas, 1966; Demarchi, 1968; Johnston, et $a 1,1968$ ), but its relation to bighorn requirements is unclear. Estimates of bighorn nutritional requirements are based on domestic sheep and other ruminants.

The nutritive requirements for domestic sheep are given in Table 2. Optimum protein, phosphorus, and calcium levels for bighorns probably exceed those of domestic sheep (Hall, 1970). Optimum requirements for deer are $13-20 \%$ total protein, $0.35-0.56 \%$ phosphorus, and 
○

○

○ 
1

[able 2. Nutrit1ve requirements for domest1c sheep based on $1201 \mathrm{~b}$. ewes, $1601 \mathrm{~b}$. rams, and $601 \mathrm{~b}$. $1 \mathrm{ambs}$ (source: NAS-NRC 1964).

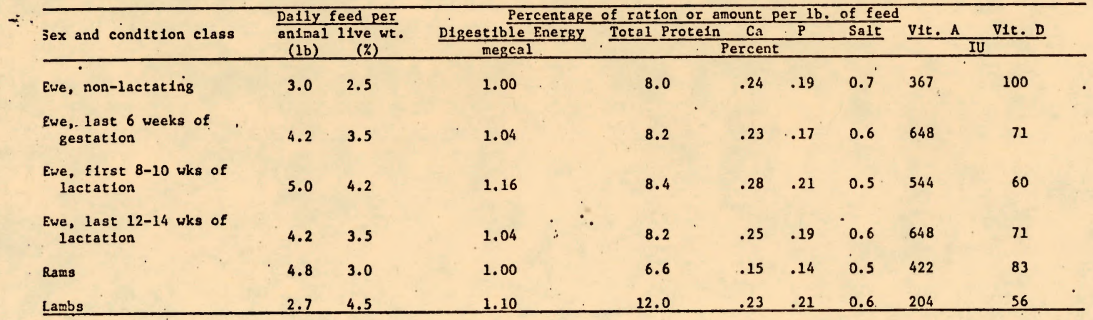


○

○

○ 
0.45-0.64\% calcium (Verme and U1lrey, 1972). The total energy requirement of bighorns exposed to the environment is also likely to be higher than the reported values based on penned domestic sheep. Some recent feeding studies have shown that 3.93 to 4.0 pounds (air-dry weight) of good quality forage per day is required to maintain one adult bighorn (Thorne, 1977, personal communication).

Low crude protein and phosphorus levels, and wide calcium-phosphorus ratios, have been reported for vegetation on bighorn ranges (Honess and Frost, 1942; McCullough and Schneegas, 1966; Demarchi, 1968). The effect of these lower than recommended values is not known. Domestic sheep subject to mild deficiencies have no apparent physiological disorders, but productive efficiency may be impaired (NAS-NRC, 1964) as well as their susceptibility to disease and parasites (Wilson, 1968; Mahon, 1969).

The nutritive value of plants usually varies during their annual life cycle. Most plants are highest in nutrients during early growth and lowest at death or dormancy. Grasses and forbs generally have larger seasonal variations than shrubs. Shrubs often maintain a relatively constant nutritive level (Cook, 1971).

The variation in nutritive quality of plants is reflected in seasonal food habits and foraging behavior of bighorns. The increased consumption of shrubs in the fall and winter is likely related to iț higher nutritive value compared to grasses and forbs at that time. Likewise, the use of immature cheatgrass during late winter and early spring is related to its early development and high nutrient content. Blood (1963) observed that California bighorns followed the development of vegetation up-slope during the spring and summer, and by late summer were foraging mainly on north exposures. Smith (1954) reported similar behavior for Rocky Mountain bighorns.

Although adult bighorn sheep occupying desert habitats apparently can subsist on dried, low quality forage for extended periods of time, the lack of succulent nutritious forage has been implicated with the low production and survival of lambs (Jones et al, 1957; Buechner, 1960; Streeter, 1970; Hansen and Deming, 1971; Geist, 1971). Research on domestic sheep has shown that nutritional deficiencies affect sexual development, fertility, production, and lamb survival (NAS-NRC, 1964).

Demarchi (1968) found that bluebunch wheatgrass, the primary forage species, retained the highest levels of crude fat compared to seven other important food plants, and had the highest levels of crude protein of the four grasses tested. Columbia needlegrass (stipa accidentalis nelsoni) had the lowest crude fat and crude protein levels of all species tested. Bluebunch wheatgrass decreases and Columbia needlegrass increases as range condition declines (i.e., successional regression). These results indicate that this vegetative type provides the greatest 
○

○

○ 
quantity and highest quality bighorn forage in the more advanced successional stages.

The term "climax" was purposely avoided to describe optimum habitat for bighorn because: 1) climax implies reduced productivity; 2) Blood (1967) found reduced diversity as a climax community had fewer grass species and forbs, and the highly palatable chametaphete, pasture sage (Artemisia frigida) was less abundant than seral stage near climax; and 3) Demarchi (1972) found higher protein in bluebunch wheatgrass plants which had been grazed than ungrazed plants. Consequently, optimum habitat would probably occur at a successional stage near climax (i.e., high composition of vigorous bluebunch wheatgrass plants and a relative diverse flora). Fire and/or light grazing may be important factors in maintaining the vegetation in this state (the influence of grazing and fire is discussed further in the cover section).

Mineral Licks: Mineral licks are an important habitat component in many bighorn populations. Generally, bighorn inhabiting higher elevations and/or more northern ranges seek out and make more use of licks than bighorn inhabiting lower elevations and/or southern ranges. One theory is that many of the low elevational areas and/or southern ranges are more alkaline than much of the granitic higher elevation ranges (Smith, 1954). Wilson (1968) identified several areas in southeast Utah that bighorn utilized which he identified as clay hill feeding sites rather than mineral licks. Wilson believed the sheep were seeking phosphorus as he also observed bighorn in the same area, eating shed deer antlers on several occasions. Shed deer antlers contain high concentrations of phosphorus and calcium.

Honess and Frost (1942) found little evidence of salt lick use by bighorn in Wyoming. They did find some licks which contained watersoluble phosphorus (readily available to the animals). Forage in the areas was found to be phosphorus-deficient, and the authors believe the bighorn were using the "licks" to supplement this forage deficiency. Heimer (1974) stated that salt licks in interior Alaska are a critical component of bighorn habitat. He believes that mineral licks also play a role in bighorn well-being because of the interchange of young bighorn rams from different herds mingling at the licks.

The use of mineral licks by bighorn populations is variable but seems to be an important element in bighorn habitats where a nutrient may be lacking in the diet. For example, Sugden (1961) did not find any mineral licks in the California bighorn range in British Columbia, Canada. Berwick (1966) reported that the use of mineral licks in Montana was one of the major factors influencing bighorn movements. 
-

○

○ 
Competition for Food with Other Grazing Ungulates: The following discussion relates only to competition for food between bighorn and other ungulates. It does not relate to competition for space which can be more detrimental to bighorn populations than competition for food. Space requirements are discussed in a later section.

In analyzing competition for food between bighorn and other ungulates, no research studies reviewed discussed range-carrying capacities for bighorn and/or other ungulates. Stocking rates, class of livestock management practices, and season of use are the major factors which influence the degree of competition for food between various species of ungulates for which definitive data is lacking in studies reviewed on this subject.

Competition with Cattle: Buechner (1960) cited several instances where cattle grazing had adverse effects on bighorns. He stated that the main problem was removal of forage on bighorn winter ranges by cattle. Competition between bighorn and cattle is highest when cattle graze bighorn winter ranges in the summer, leaving little or no bighorn winter forage, or when cattle and bighorn are on winter ranges at the same time.

Sugden (1961) found little competition for food between cattle and bighorns in British Columbia, Canada. He stated that any appreciable increase in either species would result in competition situation.

Another study in British Columbia (Blood,1961) found competition between California bighorn and cattle on bighorn spring-winter ranges. Demarchi (1965) documented cattle and bighorn in conflict on California bighorn winter range in the same Province.

Morgan (1968) documented severe competition between bighorn and cattle on the Morgan Creek winter range in Idaho.

Another factor that enters into competition between cattle and bighorn is topography. The highest degree of competition will always occur on key bighorn feeding areas which are rolling in nature or relatively flat. Spalding and Boone (1969) found little competition where British Columbia cattlemen operated within their grazing permits and the range was kept in good condition.

- Drewek (1970) studied California bighorn in southwest Idaho. He stated that most cattle use was on the flatter areas above the canyons occupied by bighorns and believed competition was low. Bighorns were observed intensively utilizing the flat areas in the spring. Since Drewek's study, the bighorn population has almost doubled (250-300 animals) and bighorn in the same area have been observed up to $1 \frac{1}{2}$ miles 
○

-

○ 
from the canyons. The flat areas up to one-quarter of a mile from the canyon rims are frequently used by bighorn now. Competition with cattle in the "level" areas adjacent to the canyon rims may now be more significant (Alan Sands, personal communication). The California bighorn in southwest Idaho are not a migratory population but occupy the same area yearlong..

McCullough and Schneegas (1966) found competition between California bighorn and cattle in the Sierra Nevadas in California was absent as the ranges of the two barely overlapped. Topography was the limiting factor to cattle distribution in this area.

In summary, the potential for competition between cattle and bighorn is greatest on winter ranges of migratory populations and yearlong ranges. Apparently, because of their ruggedness, little or no competition has been documented on bighorn summer ranges utilized by migratory bighorn populations. In areas where bighorn are confined to yearlong ranges, cattle grazing can be very detrimental.

Competition with Domestic Sheep and Goats: As previously discussed, domestic sheep pose a greater problem to bighorn from transmission of disease and parasites than any other grazing ungulate.

Sugden (1961) found slight competition between domestic sheep and bighorn as they utilized separate habitats. His greatest concern was the development of a competition between bighorn and domestic sheep on the bighorn winter range should bighorn numbers increase.

Morgan (1968) described a severe competttion problem in Idaho because domestic sheep were allowed to graze yearlong on public lands.

Jones et al. (1957) cited one incidence of competition for food between bighorn and domestic goats in California.

Competition with Wild Horses and Burros: Stelfox (1976) reported that horses in Jasper Park were competitors with bighorns for grassland forage. The large numbers present in the Park before the 1950 's played a definite role in reducing range condition and forage production.

Schallenberger (1966) in Montana felt that horses grazing in bunchgrass habitats probably were utilizing vegetation needed for bighorn in the winter. In his opinion, competition could become a serious problem if horse numbers were allowed to increase.

Competition between Rocky Mountain bighorns on Wildhorse Island in Montana was severe before the horses were removed (Woodgerd, 1964). 
0

○

○ 
Morgan (1968) in Idaho found feral burros to be serious competitors for bighorn forage on winter ranges. Domestic horses which were in trespass on BLM grazing allotments also posed an additional competition with bighorns where horses grazed on bighorn winter ranges yearlong.

Buechner (1960) cited several areas in Montana where saddle horses owned by dude ranchers were heavily grazing bighorn winter ranges during the summer. Most of the problem stemmed from land management agencies not enforcing grazing policies. Besides competition for water, Buechner (1960) cited several instances where feral burros attacked bighorns, driving them from some areas; they competed for forage and trampled and grazed bighorn ranges at such an intensity that soil erosion and loss of vegetation became devastating. Many areas inhabited by bighorn have extremely frail soils and are in low precipitation zones which cannot tolerate trampling or grazing by large herbivores.

The most intensive work known on the subject of feral burro competition with bighorn was by Miriam A. Romera (1975). In a two-year literature review and social attitude survey, two of her conclusions were:

1. "The wild burro is adversely affecting desert ecosystems, causing widespread damage to desert plants, soil, and pavement."

2. "Burros are adversely affecting native wildlife, such
as desert bighorns."

Competition with Elk: Elk, like bighorn, are primarily grazers, and serious competition for food between these two species can occur. However, a few remaining California bighorn populations are located in margin elk habitat. The possibility of elk-California bighorn competition depending on future transplants of either species could easily be realized.

Morgan (1968) stated that competition between elk and Rocky Mountain bighorn in Idaho was slight because elk wintered at higher elevations and in deeper snow than the sheep.

Competition for grass forage between elk and bighorn was documented in the Rocky Mountain National Park of Canada, the degree of which was not stated (Stelfox, 1976) while Schallenberger (1966) noted severe competition between the two in Montana.

Constan (1972) studied bighorn in Gallatin Canyon of Montana. He stated that severe competition between elk and bighorn could occur if deep snow forced both species onto the same winter ranges. 
○

0

○ 
Several examples of excessive elk numbers resulting in habitat damage to both elk and bighorn are cited by Buechner (1966).

Competition with Deer: Buechner (1960:150) states "It is generally assumed that deer are primarily browsers, but there is accumulating evidence of greater use of grasses, especially new fall, winter, and spring growth." Generally, there is a habitat separation between deer and bighorn sheep, but if deer overrun their ranges, both species will suffer. Buechner (1960) cited several conflict areas in the U. S. between the two species.

Morgan (1968) found Rocky Mountain bighorn-mule deer forage competition in Idaho to be a definite problem on bighorn winter ranges. Deer populations were at an all-time high during this study, and bighorn utilizedbrowse on some of the winter ranges that Morgan studied.

Direct competition for food during the spring and winter was documented by Drewek (1970) in southwestern Idaho on a California bighorn yearlong. range.

Berwick (1968) and Schallenberger (1966) found competition for food between deer and bighorn during the winter when forage and space availability was restricted. Cooperrider (1967) in Montana believed competition between the two species only occurred during the winter.

Demarchi (1962), Blood (1961), and Sugden (1961) found little competition between mule deer (Odocoileus hemionus) and California bighorn in British Columbia, Canada. Lack of competition between California bighorn and deer because of separation of range use areas was found by McCullough and Schneegas (1966) in the Sierra Nevada Mountains of California.

From the above discussion, it is evident that deer and California bighorn can be forage competitors, but the severity of competition varies from herd to herd, depending on habitat conditions and the size of each population.

Competition with Bison and Antelope: No studies concerning possible competition between.bighorn and buffalo (Bison bison) are known. The possibility of bison occurring on bighorn ranges is highly unlikely.

Drewek (1970) found that antelope (Antelocapra americana) rarely use the flat areas above the canyon rims utilized by California bighorn (see section on competition for food with cattle). Therefore, competition for food between these two species was negligible.. In most habitats, competition between California bighorn and antelope is unlikely. 
○

○

○ 


\section{Competition with Mountain Goats: Geist (1971) in British}

Columbia, and Vaughn (1975) in the Wallowa Mountains in Oregon, expressed concern that bighorn and mountain goats might compete for forage should weather conditions force both species to the same area for forage. Rutherford (1972) believes that the habitat requirements between bighorn and mountain goats are similar and in a competitive situation mountain goats would prevail.

\section{Intraspecific Competition: Intraspecific competition can} occur on areas of limited range, during periods of heavy snow and foraging areas are limited, and when populations exceed range-carrying capacities. One of the first indicators of intraspecific competition or over-populations would be a lower birth rate (Geist, 1971). This would be reflected in low lamb-ewe ratios. Constan (1972) felt that Rocky Mountain bighorns in Montana's Gallatin Canyon were suffering from interspecific competition based on the heavy utilization of bluebunch wheatgrass (Agropyron spicatum).

\section{Water:}

Numerous studies have documented the importance of free water to desert bighorns as a habitat requirement. The need for water will vary with the time of year, temperature, vegetation succulence, and type of animal. Monson's (1958) work on the Kofa and Cubeza Prieta Refuges showed that it was necessary for bighorn to drink water at least during dry, hot periods. Wilson (1971) determined the home range of one desert bighorn ewe in southern Utah over a five-year period. During the late spring, summer, and early fall, water availability was the major factor which influenced her home range.

Amount: The amount and frequency of water consumption is related to the type of food being eaten, activity, and climatic conditions. Koplin (1960) found that six penned desert bighorn ( 2 ewes, 2 suckling lambs, and 2 rams) watered daily during the summer. Each sheep averaged 1.3 gallons per day. He noted that rams drank $1 \frac{1}{2}-2 \frac{1}{2}$ gallons of water per day and ewes as much as 2 gallons per day in another area. McQuivey and Leslie (1976) observed that desert bighorn rams in the River Mountains of southern Nevada watered several times a day during the rut. Work in New Mexico by Kennedy (1957) indicates that access to water is necessary for ewes after they have lambed, and ewes with nursing lambs were observed watering 1-2 times daily (Wilson, 1968).

Availability: The distance between water sources has been found to control habitat use. Ferrier and Bradley (1970) found no bighorn beds more than four miles from water on the Desert National Wildlife Range in southern Nevada. Denniston (1965) found bighorns in the River Mountains 
0

○

○ 
of southern Nevada concentrating within one-half mile radius of water during the summer, and Blong and Pollard (1968) found ewes, lambs, and young rams stayed within three-fourths of a mile of water during July and August in the Santa Rosa Mountains of California. The older rams would travel as far as three miles to water and made fewer trips than the other class of animals. Wilson (1968) found bighorn ranged no further than $1 \frac{1}{4}$ miles from water ( $99 \%$ confidence limits during dry periods) regardless of the season of the year. All of the preceding information suggests that optimum conditions would be met if sources were distributed at one-mile intervals or less.

Wilson (1968) stated that water developments should never exceed 7 miles apart, that is, a bighorn should never have to travel more than $3 \frac{1}{2}$ miles to a water source. This placement can be considered the maximum spacing between water sources.

Type of Water Source: Although bighorn behavior varies, they are generally nervous when coming to water (Wells and Wells, 1961; Wilson, 1968; Hansen, 1971). Consequently, the characteristics of water sources are an important habitat factor. Sources of water located several hundred yards from escape terrain are less desirable than those located within or adjacent to rugged terrain. Likewise, sources of water surrounded by tall, dense vegetation are poorer watering sites than those permitting optimum visibility (Hansen, 1971).

Competition for Water: Competition for water between large herbivores can occur in areas where the sources are small and widely dispersed. However, in the case of feral burros and bighorn, other factors come into play. Buechner (1960) described several instances where feral burros affected bighorn by (1) driving bighorn from some watering areas; (2) befouling waterholes by trampling and defecation; and (3) utilization of water in some waterholes to the point it was unavailable to bighorn.

\section{Cover:}

Many of the cover requirements have been previously discussed in the sections "General Habitat Characteristics" and "Vegetative Types." This section primarily deals with "escape cover" and its use by bighorn in relationship to the other habitat requirements previously discussed. The extent and distribution of escape cover in relationship to the other habitat components is of major significance as in any 24-hour period a bighorn will spend an average of 12 or more hours in "escape cover (Wilson, 1968). 
○

o

○ 
Escape Cover: Bighorns depend upon highly variable precipitous and dissected terrain (escape cover) for security, predator escape, and lambing areas. Ferrier and Bradley (1970) and Breyen (1971) working in separate ranges in southern Nevada, and Wilson (1968) working in southwestern Utah, found the density of bighorn beds or pellet groups to be closely correlated with slope. Based on pellet group counts, Blood (1961) determined that $91 \%$ of the bighorn use occurred on slopes in excess of $30 \%$. Oldemeyer et al. (1971) investigated bighorn sheep habitat use in Yellowstone National Park (Table 3). Eighty-nine percent of their observations were made in rugged terrain. Seventyseven percent of the California bighorns observed during aerial surveys conducted from August 1975 to February 1976 were within rugged terrain although it is not known what percentage of the sheep moved to escape terrain from hearing the plane before they were sighted (Paul Hanna, Idaho Dept. of Fish and Game, personal communication).

Table 3. Habitat preferences of bighorn sheep on Yellowstone National Park winter ranges, 1965-1966 (source: Oldemeyer et al, 1971).

Habitat

Number observed

Terrain:

Steep

Rocky Outcrop

Ridgetop

Hilly

Leve1

Escape Habitat:

Occupying

Less than 100 yards

100 Years - 0.25 mile

Vegetative Type:

Forest

Grass

Shrub

Activity (\% of Animals Observed)
Resting Fll $\quad$ Feeding Fleeing Activities

463

31

12

45

7

6

35

54

11

10

81

9
680

35

13

35

14

4

17

67

16

16

75

9
61

1,204

51

36

39

13

0

0

14

36

8

4

26

85

60

14

2

73

27

13

78

0

Ewes will not venture as far from rugged terrain as rams (Blood, 1963; Wilson, 1968; Drewek, 1970). Blood (1963) observed ewe bands with young lambs migrating across a river and almost twice as far as ram groups to reach summer ranges which were more rugged than those occupied by ram groups. Other researchers have observed that ewes typically select the most rugged and remote portions of their habitat for lambing and as a nursery (Smith, 1954; Wilson, 1968; Welch, 1969; Geist, 1971; Hansen, 1971; Demarchi and Mitche11, 1973). 
0

○ 
Bighorns will use hilly and flat terrain (Blood, 1963; Denniston, 1965; Geist, 1971; Oldemeyer et al., 1971), but the extent to which they will venture from rugged terrain to forage or obtain water is limited and variable between populations. Oldemeyer et al. (1971) did not observe bighorns more than 0.25 mile from escape terrain, and only $15 \%$ were seen between 100 yards and 0.25 mile from escape terrain (Table 3). Although California bighorns were observed up to 1.5 miles from their canyonland habitat in southwestern Idaho during aerial surveys, the average distance was 275 yards (Paul Hanna, personal communication). Table 4 depicts the general relationship between bighorn use and the distance from escape terrain.

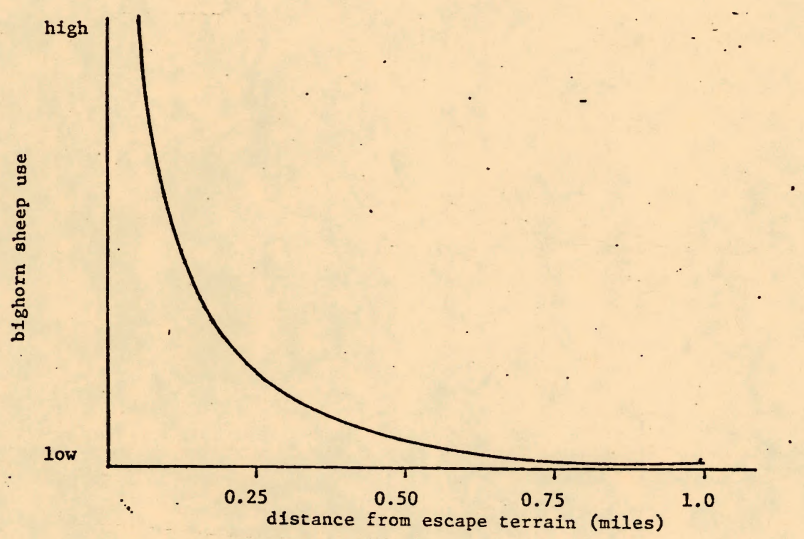

Table 4. General relationship between the amount of bighorn sheep use and distance from escape terrain.

Wilson (personal communication) believes that rolling or flat areas up to two miles frotn escape cover are used more by bighorns and, more important than what has been documented, for the following reasons: 
○ 
1. Use of such areas are no longer available to many bighorn populations because of competition with livestock, roads and highways, fences, housing developments, agricultural development, etc.

2. Bighorns are of ten not observed in these areas as the sheep are generally extremely alert when away from escape cover and see or hear an observer (whether on foot or in a helicopter, airplane, 4-wheel drive vehicle, etc.) and retreat to escape cover before being observed.

3. Generally, bighorn do not bed or rest in flat or rolling terrain, and therefore the incidence of pellet groups and beds are not as abundant.

4. Bighorn are more prone to move slower and stop and watch observers when in escape cover and are more readily sighted than in flat, open terrain.

5. Rolling or flat areas generally have deeper soils, and thus higher plant densities and plant nutrition. Therefore, bighorn can satisfy their nutritional demands faster and spend less time feeding in flat or rolling terrain than in escape cover which is generally of shallow soils and less dense vegetation.

\section{Space:}

The space requirement for bighorn is probably the most important habitat requirement and the least understood due to the variability of bighom behavior between various populations or even individuals within a population. For example, Rocky Mountain bighorn (Ovis canadensis canadensis) can be photographed from the window of a car in Banff and Jasper National Parks, Canada, and in Yellowstone National Park the sheep show little or no reaction to such disturbances. In other areas, extreme caution must be used in approaching a bighorn because, if a vehicle or person is sighted as much as a mile away, they will flee immediately. Some populations need only to encounter vehicles or people on an incidental basis, and they will abandon the area. Apparently, every bighorn and bighorn population has a threshold level of tolerance to any set of circumstances. Once that level of tolerance is exceeded, even though food, water, cover, and optimum habitat characteristics are available, abandonment of the area will result. Snow, plant regression or successional stages, density of other grazing ungulates, and various human activities can reduce the space required to maintain a thrifty California bighorn population.

Area Required and Densities: The amount of living space required by bighorns is dependent upon habitat productivity and the interspersion of food, cover, and water and other land uses. Based on population data of bighorn sheep occupying very xeric (Breyen, 1971) and mesic (Woodgerd, 1964) habits, densities vary from 0.3 to 20 bighorn per square mile, 
0

○

0 


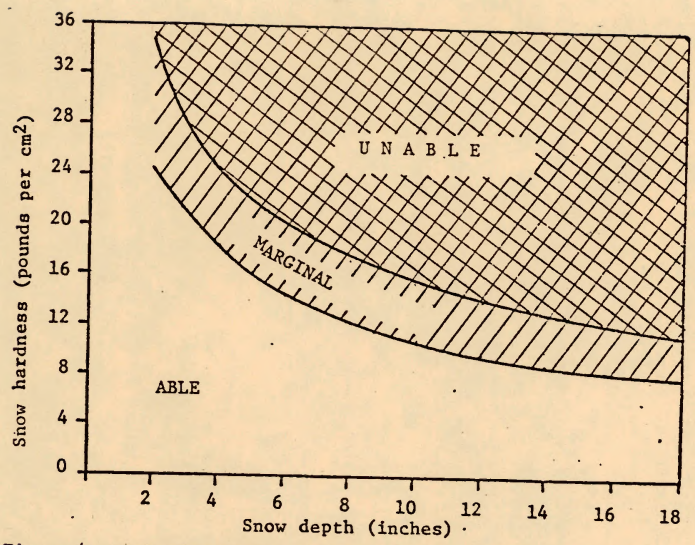

Figure 4. Relationsh1p between depth ( inches) and hardness (pounds per $\mathrm{cm}^{2}$ ) of snow to the ability of sheep to penetrate it to obtain food (calculated from data in
Nichols 1974).

formerly abused range area (overuse by livestock) can result in an increase in desirable grasses and subsequent increase of the bighorn sheep population. Morgan (1968) recomended removal of livestock and sagebrush from bighorn winter ranges in order to obtain a more desirable grass range. Berwick (1966) in Montana believed that elimination of desirable forage and loss of grasslands by shrub and tree invasion were the result of overgrazing and fire suppression.

Competition with Domestic Livestock: Irvine (1969) observed that cattle in bighorn habitat caused desert bighorns to cease using areas of their range in Utah. Wilson (1969) in the same study area determined the average distance bighorn were observed from cattle was 6.4 miles at the $99 \%$ confidence limits. Competition for space rather than food or water was the reason given as no differences in bighorn habitat between areas of cattle use and no use could be determined.

No studies are available on the space requirement between bighorn and domestic sheep. Looking at space competition between bighorn and goats could give a clue. Wilson (1968) found neither bighorn nor any signs of bighorn in an area utilized by feral goats in southeastern Utah. Historically, before the goats were introduced, bighorn had been observed all through the area. 
○

○

○ 
Weaver, et al. (1968) did not believe there was much competition between domestic livestock and bighorn sheep except in sparse water supply areas in desert areas of California. Competition for food could result in the vicinity of these water sources. He believed that limited cattle grazing in areas of adequate water supplies could possibly be beneficial to bighorns by opening bushy areas around the water sources. Most bighorn biologists believe this would be an unacceptable practice because of the difficulty often encountered with regulating livestock use in rough terrain.

Competition with Wild Horses and Burros: In reviewing the literature, few studies related directly to space competition between feral horses and/or burros. However, that the subject has not been addressed per se does not mean a review of the literature will not give some insight into the question. For example, in a presentation on burrobighorn relationships, data were presented to substantiate that there was no competition between burros and bighorns. When asked after the presentation if the area occupied by burros was historic bighorn range, the reply was yes. The question was asked, if the burros were removed from their present range, would bighorn reoccupy the area. Again the answer was yes. (Wilson, 1976): This example points out that too - often research identifies the existing situation without consideration being given to the historic situation. The absence of bighorn on many historic ranges invaded by burros or horses suggests that interspecific space competition is significant although documentation is lacking.

Competition with Deer and Elk: Wilson (1968) found the average distance between mule deer concentrations and bighorn was 8.1 miles with a range of 2.5 miles to 13.8 miles at the $99 \%$ confidence limits. He stated that competition for space and not food or water was the problem. When deer migrated from their summer range in the Abajo Mountains to the mesas in the bighorn yearlong range, the bighorn would immediately migrate to the adjacent canyons. When the deer migrated back to the Abajo Mountains even for short periods of warm weather in the fall or early winter and again in the spring, the bighorn would immediately move to the mesas.

No studies of elk-bighorn space conflicts were found in reviewing the literature. However, no references were found where elk and bighorn were observed together or in close proximity to each other.

Competition with Man and His Associated Activities or Developments: Historically, humans have had a definite and lasting adverse impact on California bighorn populations and habitat, particularly the space requirement. Many areas of western North America have adequate food, 
0

o

0 
water, cover, and habitat characteristics to reintroduce California bighorn or expand existing populations except for space. Man, his activities or developments, will continue to be the greatest limiting factor to the bighorn. In the past, the remoteness of many ranges has hindered human occupancy and development. Preservation of habitat and space is a key factor to the future existence of the California bighorn.

Hunting: Welles and Welles (1961) reported one small band of desert bighorn sheep (Ovis canadensis nelsoni) to hold up traffic as they crossed the highways in Death Valley National Monument. In this area and the examples discussed earlier about bighorn reactions to man in Banff and Jasper National Parks in Canada, these populations have learned to tolerate man and his activities, and none of the populations are hunted. These populations have learned over long periods of time that man or his. activities pose no threat to them.

In remote areas or areas where annual hunting is allowed, generally bighorns avoid areas of high to moderate human activity.

Welles and Welles (1961) and Geist (1971) feel that hunting can have a definite affect on bighorn sheep distribution and habitat use. Geist (1971) studied Stone sheep (Ovis dalli stonei) in British Columbia and reported two occasions where hunting of a group of rams caused abandonment of the areas inhabited by the sheep for several months. Welles and Welles (1961) attributed hunting as the reason for the absence of bighorn in some areas of Death Valley National Monument.

Geist (1971) believes that hunting would cause less loss of sheep habitat if done on summer ranges of migratory populations whereas hunting on winter ranges could eliminate use in an area of critical winter range, thus having an adverse effect on a bighorn population. He also stated that if a bighorn population is on a yearlong range, hunting will not lead to habitat abandonment. VanDyke (1977, personal communication) stated that hunting of rams of California bighorn on Steens Mountain in Oregon did not result in habitat abandonment but could possibly force rams into new areas. This population occupies a mountain range separated from other ranges by broad valleys where ranches, fences, roads, etc., serve as barriers.

Outdoor Recreation Pursuits: Several types of activies fall under this heading: hiking, backpacking, picnicking, camping, skiing, and photography. Each will have an adverse impact on bighorn as they infringe on space because it brings man into bighorn habitat. 
○

○

0 
Quantitative studies concerning the effects of these types of activities on bighorn are limited. The impact of human disturbance on bighorns varies with the regularity and magnitude of the disturbance. For example, one backpacking encounter a week is probably permissible with little or no measurable effect on the sheep. Daily encounters between bighorn and packpackers could result in bighorn abandonment of an area.

The backpacker and camper probably pose more problems than the hiker, picnicker, and photographer because the former types will tend to stay in an area longer and consequently have a greater chance of disturbing animals before leaving (Nelson, 1966).

Welles and Welles (1961) found that the increase of people visiting waterholes resulted in bighorns discontinuing the use of some water sources.

Van Dyke (1977, personal communication) states, "During my study of the California bighorn on the Steens Mountain in southeastern Oregon, I witnessed situations where human access possibly limited sheep distribution. Sheep were not observed in the upper basins of two canyons until after the first snows fell and undesirable weather conditions prevented human use of these areas. Some prime bighorn summer range habitat is found in these basins, but appears to be uninviting most of the summer because of the presence of hikers, fishermen, etc. My experience is that bighorn spooked by me ran until I was out of their sight. On one occasion, I observed a group of ewes, lambs, and young rams traveling a distance of approximately one mile before resuming a normal state of activity."

Kornet (1977, personal communication) reported that California bighorn on Hart Mountain, Oregon, which were disturbed by her, left feeding and bedding areas and did not return to the areas for two to three days.

Dunaway (1971) reported a decline in native California bighorn herds in the Sierra Nevada Mountains in California. He attributed the declines to increased recreation use by hikers, backpackers, picnickers, etc., in bighorn sheep use areas. Areas of high people use had low sheep use and vice versa.

Human use--primarily skiers-on Mt. San Antonio, California, resulted in a decrease of California bighorn use. The sheep moved to more remote, less desirable areas (Light, 1971). 
○

o 
Cross-country skiing is another activity which can produce competition for space between bighorn and humans. Increased human activity, particularly on critical winter ranges, can impose additional stress on bighorns during a period of the year when energy conservation by the sheep is of paramount importance. Again, it is the regularity and magnitude of the disturbance which will dictate the severity of the activity to a bighorn population.

Light's (1971) study in California revealed that 0 to 500 visitor days per year had no determined affect on bighorn habitat use. Over 500 visitor days per year resulted in avoidance of historic quality bighorn habitat.

Human Occupancy and Development: Some of the greatest impacts to the bighorn habitat requirement of space are the elements man brings with him, such as vehicles, livestock, road development, etc. In the case of human occupancy, competition for food, water, and cover can also result.

Any permanent dwelling in bighorn sheep habitat will adversely impact the habitat, the bighorn population, or both. It is the dwelling location, type of dwelling, number of dwellings per unit area, and the associated use of the dwelling(s) which will determine the degree of impact. For example, a summer cabin in or adjacent to a lambing area can result in complete abandonment by bighorn. A summer cabin located in a low bighorn use area on a sumuter range could have little impact whereas five summer cabins within a two-mile area may result in abandonment of the summer range by bighorn.

One resort may have far-reaching implications as many more people would be brought into the area, and the possibility of bighorn abandonment of the area would be greater. Spalding and Boone (1969) cited an example where the development of view lots on Vaseux Lake, British Columbia, was responsible for bighorn abandoning a portion of a critical winter range.

Dunaway (1970) recommended close monitoring of the California bighorn populations in the Mount Baxter and Mount Williamson herds because of human occupation and disturbance to the sheep. "Should such effects occur, steps must be taken to limit human use of the ranges." (p. 143)

A future which will bring more people wanting more recreation in the form of resorts and condominiums in remote areas definitely poses a threat to many bighorn populations. Also, areas of habitat suitable for California bighorn reintroductions are equally threatened. 
o

o

0 
Off-Road Vehicle Use: DeForge (1972) studied a bighorn population in the Buck Point area of the San Gabriel Mountains of California. Bighorn were commonly sighted in this area prior to June. "June also brought the beginning of summer vacation which resulted in an influx of traffic into the area. Motorbikes had no trouble getting past the locked gates, and consequently could often be seen and heard throughout the Buck Point area. The weekend flow of this type of traffic was tremendous at times." Bighorn avoided this area during this time but were seen regularly after the use stopped in July. The affect of this displacement on the population was unknown.

Jorgensen and Turner (1973) found off-road vehicles (4-wheel drives, in this case) resulted in bighorn being reluctant and in some cases not crossing a 4-wheel drive vehicle road when the bighorn were going to water in Coyote Canyon of Anza-Borrego State Park in California. He concluded, "bighorn sheep are surviving with the jeep trail in Coyote Canyon, but increased use of this trail would make their survival difficult, if not impossible." This road has subsequently been closed for bighorn habitat and space preservation (Weaver, 1977, personal communication).

Snow machines, four-wheel drives, and motor bikes present three additional problems to bighorn other than the space limitation.

1. Allowance of greater access and disturbance by humans into habitats occupied by bighorns.

2. Disturbance to bighorn created by the noise of the vehicles even though the vehicles are never seen by the sheep. Elk were observed from an airplane running as much as one mile ahead of snowmobiles, even though the elk never saw the snow machines (Wilson, 1977, personal communication).

3. The possibility of destroying habitat from vegetative disturbance, soil compaction, and soil erosion.

In areas of migratory bighorn populations, some ORV use could be incorporated in bighorn habitats. For example, snow machines could be used during the winter on bighorn summer ranges while the sheep were on the winter range. Boating and other activities could be accommodated during the summer adjacent to bighorn winter ranges while the bighorn were on their summer range.

Roads: The presence and associated use of the roads in bighorn habitat can be highly detrimental. Wilson (1969) found the mean distance. that bighorns occupied habitats from Highway 95 in southeastern Utah 
-

○

○ 
was 11.0 miles with a range of 1.3 to 22.7 miles ( $99 \%$ confidence limits). No difference in the quality of bighorn habitat (unoccupied by bighorns) adjacent to the road and habitats occupied by bighorns could be determined. Highway 95 at the time was not paved and received low use.

In a discussion with Yoakum (1971), John Russo stated that access roads into prime bighorn ranges along the Colorado River in Arizona were pushing the bighorn sheep further back into the mountains.

Another impact of roads is the dissection of bighorn ranges into small, more discontinuous areas with the ultimate result of decreasing bighorn numbers.

Timber Harvest: The majority of the California bighorn in the United States generally occupy grassland-shrub habitats in which there is little or no harvestable timber. Some populations in British Columbia, Canada, California, and some historic habitats are associated with timbered habitats (Blood, 1959; Sugden, 1961; Spalding and Boone, 1969).

DeForge (1972) observed that bighorns avoided part of their range during a logging operation.

Sugden (1961) stated that logging would probably have little influence on most California bighorn ranges because of the inaccessibility and inferior tree quality of these areas. He also felt that cutting mature stands of trees would improve range conditions for big game species. Logging would also mean increased human disturbance and perhaps poaching of sheep.

Spalding and Boone (1969) stressed that, although logging would mean road building and increased access to bighorn areas, it would eventually make additional range available to the bighorns.

Fences: Fences can definitely reduce the space occupied by bighorn. With few exceptions, bighorn tend to crawl under or through fences rather than jump them. Thus, woven wire fences or barbed wire fences with closely spaced strands can be effective barriers to bighorn.

The fencing problem is more likely to occur on winter ranges than on summer ranges due to their ruggedness and remoteness.

VanDyke (1977, personal communication) relates the following observation. "Two mature rams fed up to a four-strand barbed wire fence where they stopped feeding and stood looking through to the other side. They both walked back and forth along the fence feeding and looking around for approximately 10 minutes. When they decided 
0

0

0 
to go, they followed the fence approximately 250 yards up the hill to where it terminated and crossed above it. They did not try to go through the fence; and the fact that they moved uphill to get around it suggests that they may have encountered it before."

In the above quotation, VanDyke suggests that these bighorn had encountered the fence before. Some clue as to what can happen to bighorn who have never-encountered a fence or bighorn is available from Welch (1971) in Arizona. Twelve percent of the mortalities (141 observations) of bighorn found dead in Arizona and southern Nevada were attributed to fences and cables. All were rams with half curls or larger. The rams became entangled by passing the top or second strand above the tips of the horns and in back of the head. In struggling to get free, all suffered lacerations of the neck and throat and died from loss of blood.

Mineral and Fossil Fuel Corridors: To date, California bighorn sheep have had little conflict with mineral development because the magnitude of mineral and fossil fuel development has not been significant in most California bighorn habitats. The possibility of mining is an area of definite concern. Strip mining for fossil fuels and minerals would have devastating effects on bighorn populations through loss of habitat. Several authors (Sugden, 1961; Blood, 1961; Demarchi, 1965) stress the fact that prime bighorn sheep ranges are ranges in excellent condition and usually in a climax situation. Strip mining would definitely disrupt the vegetative complex and it would take years, if ever, before prime range conditions were again attained. Sugden (1961) states that mining would tend to increase human disturbance in bighorn areas and may increase poaching; both would decrease numbers. Intensive illegal hunting associated with mineral exploration and development has been documented in southeastern Utah (Wilson, 1968).

In northeastern British Columbia, Pendergast (1977) correlated a decrease in mountain goat (Oreoamnos americanus) numbers with exploration for coal. He found the apparent causes for the decline were increased hunter access and disturbance of habitat with no reclamation.

\section{Hydroelectric and Associated Developments: Reservoir} construction and the associated developments can seriously affect bighorn populations as well as reduce habitat and space. Seventeen bighorn ( $12 \%$ of all bighorn found dead other than from legal hunting) drowned in reservoirs or associated developments in southern Nevada and northern Arizona. Two drowned in reservoirs, four in canals, and eight in the Colorado River in the Willow Beach area between Lake Mead and Lake Mohave. 
○

0

○ 
In interviewing an elderly resident of the White Canyon area in southeastern Utah on the Colorado River, Wilson (1977, personal communication) was told that bighorn were commonly seen crossing the shallow riffles in the late sumer. Since construction of Glen Canyon Dam, bighorn no longer migrate from east to west or west to east across Lake Powell.

Damming of rivers for reservoir development can flood important bighorn use areas (lambing grounds, winter ranges, etc.) and increase human access. Significant reductions in bighorn space, habitat, and total loss of some bighorn populations can result from dam construction (Ferrier, 1974).

Powerline construction associated with hydroelectric or other electrical power sources has little impact to bighorn space requirements. It is the associated road and subsequent increased human use which will create major problems. Should powerlines be constructed without road construction, the lines need periodic checking by helicopter or lowflying fixed-wing aircraft. Solitude during critical periods is important in maintaining bighorn populations with regard to their space requirement. Critical periods are the lambing season; hot, dry summer periods; and conditions of extreme cold and snow when the bighorns are under considerable stress. 
○

o 
CHAPTER IV. RESPONSE OF CALIFORNIA BIGHORN TO HABITAT MANIPULATION OR ALTERATION PRACTICES

General Discussion:

Before any habitat alteration practices or habitat improvements are considered in California bighorn ranges, detailed study as to the effect the selected practice or improvement will have on the stability of the plant community within and adjacent to the selected area, or to a bighorn population, must be determined. For example, the placement of water development for the benefit of bighorn may attract domestic livestock, feral horses, or burros, deer, or elk into an area from an adjacent range where they had not occurred previously. The improvement could be more detrimental than beneficial.

The season of the year and the habits of a bighorn population are equally important considerations. As previously discussed, minimum disturbance to bighorn during critical periods (lambing season or when the animals are under considerable stress) should be avoided.

\section{Mechanical Practices:}

As a general rule, mechanical practices (discing, chaining, or logging) are not considered for habitat improvement in California bighorn habitats due to the precipitous terrain and fragile soils. However, gently rolling or flat areas not in excess of 30 percent slopes can generally be treated. Soil texture and precipitation patterns are major considerations when selecting a mechanical practice for vegetative improvement. Soils of a fine texture are generally less erodible than coarse textured soils. Precipitation in the form of gentle rain or snow will result in less erosion in coarse soil areas than in similar soils where precipitation generally comes in the form of thundershowers.

Plowing and Planting: Apparently there has been little plowing and planting done within bighorn habitats, probably for the reasons previously stated. Pallister (1974) indicates that bighorn sheep will make use of artificially seeded areas. Any practice which will increase in the variety of vegetative communities, particularly those reducing dense shrub stands such as sagebrush to more grassland in character, will have a positive effect on California bighorn.

Chaining: Yoakum (1971) cited an instance near Hawthorne, Nevada, where a pinon-juniper community had been chained and seeded to a mixture of browse, forbs, and grasses. He stated that transplanted bighorns "thrive on the succulent forage" now present on the area. 
○ 
Carl Mahon (1977, personal communication) reported considerable use by Nelson's bighorn in two areas of southeastern Utah where the pinonjuniper trees had been chained and the area reseeded with crested wheatgrass (Agropyron desertorum). Both seedings were on large mesas adjacent to the canyons inhabited by the sheep. He stated that rams were sighted up to a mile from the canyon rims grazing within the seeding.

Logging: Open habitat is of major importance and a California bighorn necessity (Spaulding and Boone, 1969). Thus, careful logging, such as adequate slash disposal and closure of vehicle access following logging, can be beneficial as more openings and additional foraging areas are created.

Berwick's (1966) opinion is that timber sales would be detrimental to bighorns in his Montana study area, primarily because of the associated access road development. He found that open timber with a bunchgrass understory was an important sheep feeding and bedding area during bad weather and times of snow accumulation.

Smith (1954) found lighter bighorn use in open timber during periods of snow cover than in any other cover type. However, on low elevation summer ranges, he found that bighorns tended to forage in open timber stands. The sheep also used-the timber type, particularly north-facing slopes, for a short period of time in early autumn.

From the above data, careful site selection and use of helicopter logging which will result in open timber stands with a bunchgrass understory can benefit bighorn. Also, preclusion of road access to clear cuts in selected areas would be beneficial to some bighorn population.

Herbicide Treatments:

Morgan (1968) recommended spraying or burning of sagebrush on key winter ranges followed by seeding of native grasses in Idaho for bighorn inhabiting an area of depleted rangelands.

In any California bighorn habitat where areas have been invaded by shrubs such as sagebrush, herbicide treatment is one method of increasing grass productivity. If possible, dead brush should not be left standing on the treated areas. Dead shrubs can restrict bighorn use of available forage and continue to tie up nutrients for several years. Also, herbicide treatments can adversely affect forbs.

Herbicide treatment can be used to reduce shrub competition on slopes and, in some cases, soils too risky to plow or chain. Generally, herbicide treatments in California bighorn ranges are not advised until data are evaluated and the desired results appear feasible from small control areas within the site. 
○

○

0 


\section{Fire Management:}

Most of the literature reviewed, and from the author's knowledge, agrees that fire management to enhance California bighorn habitats where trees or shrubs have reduced the foraging areas of space requirements of the sheep is the best management practice:. Forage on burned areas is more palatable and more nutritious.

Yoakum (1971) noted that bighorn make more use of grasses on old wildfire areas than on adjacent good grass ranges. Rocky Mountain bighorns were observed selecting small burned areas within their winter range on the East Fork of the Salmon River in Idaho (Loren Anderson, personal communication). California bighorn make substantial use of burned timbered areas in British Columbia, Canada (Ray Demarchi, 1977, personal communication).

In the Lostine River area of northeastern Oregon, fire destroyed a timbered area. Of the 900 acres of winter range utilized by the bighorn, 450 acres was made available by the fire (Vic Coggins, personal communication).

Fire suppression has allowed invasion of undesirable timber and shrubs on previously open Montana grasslands in bighorn habitats (Berwick, 1966). Crump (1971) also believes fire was a major factor in maintaining some bighorn ranges in Wyoming.

Controlled burning like any habitat manipulation tool must be used with discretion and careful planning. The soils, vegetation, and terrain must be suitable as well as the time of burning to insure adequate recovery and reduce erosion. Again, site by site evaluation must be exercised as fire on depleted ranges may be detrimental.

\section{Edges and Ecotones:}

Any of the aforementioned treatment practices may create or destroy ecotones. It is in the ecotone areas that maximum vegetative species diversity can be expected. Any land treatment practice should be designed to blend with the natural situation. Feathering of edges of treatments in irregular patterns is recommended to create as much edge and ecotone as the landscape will permit. This practice is especially important in layout and design of creating additional foraging areas in relation to escape cover.

\section{Livestock Grazing:}

Grazing of cattle (not horses, burros, or domestic sheep) can be used as a bighorn habitat enhancement or maintenance tool. For example, late fall or winter grazing by cattle in selected areas can result in heavy 
。

○

○ 
use of shrubs with a subsequent reduction of competition for water and nutrients between shrubs and grasses. Grass vigor and density could increase.

Demarchi (1972) reported the nutritive value of grazed to ungrazed grass plants was always higher in the grazed plants. Therefore, in bighorn populations experiencing low numbers or in areas of recent or proposed bighorn introductions, cattle could be used to maintain the nutrient quality of the grasses.

Occasional light grazing of cattle on critical bighorn winter ranges during the summer when the bighorn are on their summer range could be another instance when cattle could be grazed to benefit bighorns. Strick enforcement of animal numbers is of prime importance so that sufficient levels of forage are available for bighorn during the winter.

\section{Fertilization of Forage:}

Fertilization can often increase nutrient content and palatability of native and introduced forage species. The Oregon Department of Fish and Wildife recently started a small series of fertilization trials on deer and antelope ranges. Preliminary results indicate that nitrogen fertilization has increased herbage yield on most sites and decreased essential oil content of the sagebrush (Sneva, 1976). Work in Colorado has shown much the same results. The only reference known concerning fertilization on bighorn range was undertaken by Pallister (1974) in Montana. He had some old mine roads on his study area that had been artificially seeded and fertilized. This vegetative type was one of the most highly used for bighorns during the summer and fall periods. Colorado is doing some work with fertilization of sheep ranges, but no results are available at this time.

Fertilization of vegetation should be used cautiously. There is danger of changing botanical composition and attracting increased numbers of grazing ungulates or concentrating bighorn increasing the potential for disease and parasite transmission.

\section{Supplemental Feeding:}

Little supplemental feeding of bighorn has been undertaken. Honess and Frost (1942) believe that bighorn could be easily attracted by artificial feed. They stated that supplemental feeding was probably the only means by which substantial numbers of bighorn sheep could be maintained in the Jackson Hole area of Wyoming. 
0

o

○ 
Bear and Jones (1973) cited an instance in Colorado where alfalfa was fed to a wintering bighorn herd from 1911 to 1929. The sheep became very tame and evidently thrived on the alfalfa. An inadvertent switch to native hay in 1929 was not accepted by the sheep, and the wintering population of sheep in this area decreased substantially in the following years. The cause of the population decrease was not explained.

Robinson (1965) confined his remarks to deer. He felt winter feeding was economically and physically impractical. The same conclusions could probably be drawn for bighorn. However in the case of some catastrophic key habitat loss, a small sheep population could probably benefit from an artificial or supplemental feeding program until the habitat was rehabilitated. Supplemental feeding should never be considered as a continuing practice.

\section{Artificial Salting:}

Like all the other habitat manipulation practices previously discussed, careful evaluation of the decision to salt or not to salt should be analyzed carefully and on an experimental basis for a given bighorn population. Until conclusive data as to the positive and negative values of such a program can be fully evaluated, caution is advised. Calcium and phosphorus are essential minerals for proper bighorn nutrition. Plants on western ranges usually contain adequate levels of calcium, but phosphorus levels are usually deficient. A phosphorus deficiency or a wide calcium-phosphorus ratio may cause retarded growth, weak young, decreased lactation, failure to conceive, and other abnormalities (Dietz, 1971). DeMarchi (1968) reported low phosphorus levels and wide calcium-phosphorus ratios for the primary forage species on bighorn winter ranges in southern British Columbia, Canada.

Salting can be a valuable technique to supplement minerals, vitamins, proteins, and even medication to bighorn. Wilson (1968, pg. 119) commented, "In an enclosure in Texas five desert bighorn sheep utilized two 33-pound blocks of Moorman mintrate salt in six weeks. Moorman mintrate salt contains 42 percent protein, áll the known essential minerals, Vitamin A, Terramycin, and 14 percent salt. Since the salt was placed in the enclosure (1962), lamb mortality has ceased and reproduction has been high (Hailey 1962, 1964). Fifteen bighorn are now utilizing 50 to 60 pounds of the Moorman mintrate salt monthly at this time with no apparent ill effects (Hailey, personal communication)."

Rutherford and Schmidt (1973) measured use of salt mineral blocks on Colorado ranges. They concluded that sheep would use them, but if the mineral blocks were to be of value as a dietary supplement the formula used would have to be a compromise between salt and mineral content. They found that the block with the higher salt content was always the most preferred by bighorns. 
○

○

○ 
Smith (1954) speculated that some of the summer drift of sheep could be influenced by salt placement. Smith felt that a salting program, wisely planned and executed, could be a tool for securing good sheep distribution and resultant proper range use. He advised caution in order to avoid animal concentrations.

Sugden (1961) reported the use of salt as bait for trapping sheep, but reported it as being an insufficient attractant on the ranges studied. He speculated that salting could be used to achieve better animal distribution where the bighorns occupy restricted ranges.

Moster (1962) stated that a salting program was probably undesirable because of the danger of concentrating the naturally gregarious sheep, and the fact that there was not a proven need for salt on many areas. Sheep concentrations created by salting could lead to range overuse and buildups of parasite infections.

\section{Water Developments:}

Water development is probably the most common habitat improvement work employed on bighorn sheep range (Yoakum, 1971). Bighorns prefer fresh water. Lack of sufficient water is one of the major factors regulating animal numbers in arid areas (Jones, et al. 1957).

Water developments can definitely be a means of enlarging and/or enhancing desert bighorn habitat. Russo (1957) reports that Arizona has had great success with this aspect of habitat improvement. He states that every time they have developed water in an area, a resident population of desert bighorns moved into the affected area. Jones, et al. (1957) reported a similar experience in their California work. Blong and Pollard (1968) reported that bighorns readily adapt to new water sources in the Santa Rosa Mountains of California.

There seems to be little question that bighorns will use domestictype stock water developments. Sugden (1961) and Drewek (1970) reported that sheep would utilize livestock watering facilities. This dual use could lead to water and forage problems in some areas and is not recommended. Schallenberger (1966) felt that an intensive livestock grazing program could be detrimental to bighorn sheep unless the program were carefully planned and implemented. Much of his concern revolved around use of the forage resource, but he believed that the development of water in pristine bighorn sheep habitat could be detrimental because such development would probably attract livestock and increase forage competition. Morgan (1968) stated a similar view and recommended fencing such water developments from cattle on critical bighorn winter ranges. 
o

○

○ 
The Guidelines for Management of Desert Bighorn Sheep (Trefethen, 1975) recommend that water developments should not be spaced over seven miles apart, and they should be located and developed in a manner that will attract as little livestock use as possible. These guidelines recommend fencing of water areas, where possible, to exclude feral animals (horses and burros) and livestock. Fenced water developments should be a minimum of 100 -feet square in area.

Fencing bighorn from hazardous water sources or modifications of hazardous watering sites should also be considered. Mensch (1969) found the remains of 34 bighorn sheep in a natural tank in California. Apparently, the bighorn had fallen into the tank when attempting to get a drink and could not get out. Mortality of this nature could result in the failure of a re-establishment program with the loss of the nucleus of a transplanted population.

Snow Accumulation Manipulation:

No references or work of manipulating snow accumulations to benefit bighorn are known. Considerable work has been undertaken on forested lands concerning the effect that different timber harvest methods have on snow accumulation.

The opening of timber stands could benefit bighorn as the snow pack accumulated in openings would provide additional moisture for increased forage growth. This practice would probably be more beneficial on bighorn summer ranges where migratory bighorn populations is involved. 
o

0

0 


\section{Literature Cited}

Anderson, Loren.

1977 personal communication, BLM, Salmon District, Idaho.

Bear, G. D., and G. W. Jones

1973. History and Distribution of Bighorn Sheep in Colorado.

Fed. Aid Job Prog. Rpt., Project W-41-R-22, Work Plan No. 1,

Job No. 12, Colorado Div. of Wildlife, 232 pp.

Berwick, S. H.

1968. Observations on the Decline of the Rock Creek, Montana, Population of Bighorn Sheep. M. S. Thesis, Univ. of Montana, Missoula. 245 pp.

Blaisde11, James A.

1974. Lava Beds California Bighorn-- Was 1973 Typical? Trans. Desert Bighorn Council, p. 46-47.

1975. Progress Report: The Lava Beds Re-Establishment Program. Trans. of Desert Bighorn Council, p. 36-37.

1976. The Lava Beds Bighorn--So Who Worries? Trans. of Desert Bighorn Council, p. 46-47.

1977. Personal Communication. Lava Beds National Monument, Oregon.

Blaisdell, P., A. C. Wiese, and C. W. Hodgson.

1952. Variations in Chemical Composition of Bluebunch Wheatgrass, Arrowleaf Balsamroot, and Associated Range Plants, J. Range Mgmt. (5) : 346-353.

Blong, B., and W. Pollard. 1968. Summer Water Requirements of Desert Bighorn Sheep in the Santa Rosa Mountains, California, in 1965. California Fish and Game. $54(4): 289-296$.

Blood, D. A.

1961. An Ecological Study of California Bighorn Sheep, Ovis canadensis californiana (Douglas) in Southern British Columbia. M. S. Thesis. Univ. of British Columbia, Vancouver. 127 pp.

1963. Some Aspects of Behavior of a Bighorn Herd. Canadian Field Naturalist. $77(2): 77-94$.

1967. Food Habits of the Ashnola Bighorn Sheep Herd. Canadian Field Naturalist. $81(1): 23-29$. 
○

)

○ 
Breyen, L. J.

1971. Desert Bighorn Habitat Evaluation in the Eldorado Mountains of Southern Nevada. M. S. Thesis, Univ. of Nevada, Las Vegas.

95 pp.

Buechner, Helmut $\mathrm{K}$.

1960. The Bighorn Sheep in the United States, Its Past, Present and Future. J. Wildl. Mgt. Monograph 4: 174 pp.

Coggins, V. 1977. Personal Communication. Oregon Dept. of Fish and Wildlife, Enterprise, Oregon.

Constan, K. J. 1972. Winter Foods and Range Use of Three Species of Ungulates. J. Wildl. Monograph. 36(4):1068-1076.

Cook, C. Wayne.

1971. Comparative Nutritive Values of Forbs, Grasses, and Shrubs. 303-310, in: Wildland Shrubs - Their Biology and Utilization. 1972. USDA Forest Service. General Tech. Report INT-1. 494 pp.

Cooper, Jack R.

1973. Nevada's Desert Bighorn Sheep - 1973 Status Report.

Trans. Desert Bighorn Council. p. 31-37.

Cooperrider, A. Y. 1969. Competition for Food Between Mule Deer and Bighorn Sheep on Rock Creek Winter Range, Montana. M. S. Thesis. Univ. of Montana, Missoula. $92 \mathrm{pp}$.

Cowan, Ian McTaggart. 1940. Distribution and Variation in the Native Sheep of North America. Am. Midland Naturalist. (24):505-580.

Crump, W. 1971. The Wind River Bighorn Herd - A New Approach to Sheep Habitat Management, p. 174-180 in First Trans. North Amer. Wild Sheep Conf., April 14-15, Colorado State Univ., Ft. Collins. E. Decker. ed.

DeForge, James $R$.

1972. Mans Invasion Into the B1ghorns Habitat. Trans. Desert Bighorn Council. p. 112-115. 
o

○

○ 
DeMarchi, R. A.

1965. An ecological study of the Ashnola Bighorn Winter Ranges.

M. S. Thesis. Univ. of British Columbia, Vancouver. $103 \mathrm{pp}$.

1968. Chemical Composition of Bighorn Winter Forage. J. Range Mgmt. $21(6)$ : 385-388.

1972. Relationship of Range Quality to Range Condition in the Chilcotin Region, British Columbia, J. Range Mgmt. 26(5):345-348.

1975. Report and Recommendations of the Workshop on California Bighorn Sheep. in: The Wild Sheep in Modern North America,

p. 143-163. Winchester Press. New York. 302 pp.

1977. Personal Communication, Cranbrook, British Columbia, Canada.

DeMarch1, R. A., and H. B. Mitchell.

1973. The Chilcotin River Bighorn Population. Canadian Field

Naturalist. (87):433-454.

Deming, 0. V.

1964. Some Bighorn Foods on the Desert Game Range. Trans. Desert Bighorn Council, p. 137-143.

Denniston, Alan.

1965. Status of Bighorn in the River Mountains of Lake Mead

National Recreation Area. Desert Bighorn Council Trans. 27-34.

Dietz, Donald R.

1971. Nutritive Value of Shrubs. in: Wildland Shrubs--Their

Biology and Utilization. USDA Forest Service General Technical

Report. INT-1, p. 289-302.

Drewek, John, Jr.

1970. Population Characteristics and Behavior of Introduced

Bighorn Sheep in Owyhee County, Idaho. M. S. Thesis, Univ. of Idaho, Moscow. 46 pp.

Dunaway, David J.

1970. Status of Bighorn Sheep Populations and Habitat Studies on

the Inyo National Forest. Trans. Desert Bighorn Council. p. 127-146.

1971. Human Disturbance as a Limiting Factor of Sierra Nevada

Bighorn Sheep. in: First Trans. of the North Amer. Wild Sheep

Conf., Dept. of Fish and Wildl. Biol., Colorado State Univ., Fort

Collins. p. 165-173.

1972. Winter Food Habits of California Bighorn Sheep in the Sierra Nevada. Desert Bighorn Council Trans. 21-25. 
○

○

○ 
Ferrier, Gary J.

1974. Bighorn Sheep Along the Lower Colorado River. 1974-2050.

Trans. Desert Bighorn Council. p. 40-45.

Ferrier, J., and W. Bradley.

1970. Bighorn Habitat Evaluation in the Highland Range of Southern Nevada. Trans. Desert Bighorn Council. p. 66-93.

Franklin, J. F., and C. T. Dyrness.

1973. Natural Vegetation of Oregon and Washington. USDA Forest

Service, Genl. Tech Report PNN-8. 417 pp.

Geist, Valerius.

1971. Mountain Sheep - A Study in Behavior and Evolution.

Univ. of Chicago Press, Chicago. 383 pp.

1975. On the Management of Mountain Sheep: Theoretical Considerations. in: The Wild Sheep of North America. p. 77-105.

Winchester Press. New York. 302 pp.

Graf, William.

1971. Habitat Protection and Improvement. in: The Desert Bighorn Its Life, History, Ecology, and Management. p. 21-1 to 22-15.

Desert Bighorn Council, Mesa, Arizona. 644 pp.

Hailey, Tomny L., R. G. Marburger, R. M. Robinson, and Keith A. Clark. 1972. Disease Losses in Desert Bighorn Sheep, Black Gap Area.

Trans. of Desert Bighorn Council. p. 79-83.

Halls, Lowell $\mathrm{K}$.

1970. Nutrient Requirement of Livestock and Game. Range and Wildlife Habitat Evaluation - A Research Symposium. USDA Forest Service.

Misc. Publ. No. 1147. p. 10-18.

Hansen, Charles G.

1971. Habitat. in: The Desert Bighorn - Its Life History; Ecology, and Management. p. 3-1 to 3-30. Desert Bighorn Council, Mesa, Arizona. 644 pp.

1976. Bighorn Sheep Populations of the Desert Game Range. Journal of Wildlife Mgmt. 31(4):693-706.

Hansen, Charles G., and O. V. Deming.

1971. Lambs. in: The Desert Bighorn - Its Life History, Ecology, and Management, p. 10-1 to 10-15. Desert Bighorn Council, Mesa, Arizona. 644 pp. 
○

○

- 
Heimer, W. E.

1974. The Importance of Mineral Licks to Dall Sheep in Interior Alaska and Its Significance to Sheep Management. Proc. of the Biennial Symposium of the Northern Wild Sheep Council, p. 49-63.

Helvie, Jack B.

1971. Bighorns and Fences. Trans. Desert Bighorn Council. p. 53-62.

Honess, R. F. and N. M. Frost.

1942. A Wyoming Bighorn Sheep Study. Bu11. No. 1. Wyo. Game and Fish Dept., Cheyenne. pp. 127.

Irvine, C. A.

1969. The Desert Bighorn Sheep of Southeastern Utah. Pub1. No. 69-12. Utah State Div. of Fish and Game, Salt Lake City. pp. 99.

Johnson, R. L.

1975. An Evaluation of Bighorn Sheep in the Sinlahekin Area of North Central Washington With Notes on Other Washington Sheep. Wash. Dept. of Game. 40 pp.

Johnston, A., L. M. Bezeau, and S. Smoliax. 1968. Chemical Composition and in Vitro Digestibility of Alpine Tundra Plants. J. Wildl. Mgmt. 32(4):773-777.

Jones, F. L., F. G. Flittner, and R. Gard. 1957. Report on a Survey of Bighorn Sheep in the Santa Rosa Mountains, Riverside County, California. California Fish and Game. 43(3):179-191.

Jorgensen, Mark C. and Robert E. Turner, Jr. 1973. The Desert Bighorn Sheep of Anza-Borrego Desert State Park. Trans. Desert Bighorn Council. p. 81-88.

Kennedy, C. A. 1957. Seasonal Water Requirements. Trans. Desert Bighorn Council. p. 52 .

Kilpatrick, Jack.

1975. Bighorn Transplant in Texas. Trans. Desert Bighorn Council. p. 38 .

Koplin, James $R$.

1960. New Development on Water Requirements on the Desert Game Range. Trans. Desert Bighorn Council. p. 54-57. 
○

○ 
Kornet, $\mathrm{K}$.

1977. Personal Communication. Oregon State Univ., Corvallis.

Lauer, Jerry, and James M. Peek.

1976. Big Game-Livestock Relationships on Bighorn Sheep Winter Range, East Fork Salmon River, Idaho. Univ. of Idaho, Forest, Wildlife, and Range Exper. Sta. Bul. 12, Moscow. 44 pp.

Light, J. T.

1971. An Ecological View of Bighorn Habitat on Mt. San Antonio.

Proc. of the First Symposium of the North Amer. Wild Sheep Council. p. 49-63.

Mahon, Car1 L.

1969. Mineral Deficiencies in Desert Bighorns and Domestic Livestock in San Juan County. Trans. Desert Bighorn Council, p. 27-33.

1977. Personal Communication, Vernal BLM District, Utah.

McCullough, D. R. and E. R. Schneegas.

1966. Winter Observations on the Sierra Nevada Bighorn Sheep.

Cal. Fish and Game. 52(2):68-84.

McQuivey, Robert P. and David M. Leslie, Jr.

1976. The Status and Trend of Desert Bighorn Sheep in Nevada -

River Mountains. Nevada Fish and Game Department, Special Report

77-9. $31 \mathrm{pp}$.

Mensch, Jerry L. 1969. Desert Bighorn (Ovis canadensis nelsoni)

Losses in a Natural Trap Tank. Cal. Fish and Game. $55 \overline{(3): 237-238 .}$

Monson, Gale M.

1957. Seasonal Water Requirements. Trans. Desert Bighorn Council, p. $51-55$.

1958. Water Requirements. Trans. Desert Bighorn Council. p. 51-55.

Morgan, J. K.

1968. Rocky Mountain Bighorn Sheep Investigations. Fed. Aid Job.

Prog. Rpt., Proj. W-85-R-19, Job 11, Idaho Fish and Game Dept.,

Boise. $80 \mathrm{pp}$.

1971. Rocky Mountain Bighorn Sheep Investigations. Job Prog. Rpt., Project. W-142-R-1, Idaho Dept. of Fish and Game, pp. 155. 
○

0

0 
Moser, C. A.

1962. The Bighorn Sheep of Colorado. Tech. Publ. No. 10.

Colorado Game and Fish Dept., Denver. 49 pp.

Murie, A.

1940. Ecology of the Coyote in the Yellowstone. National Parks Fauna Series No. 4. U. S. Gov.Printing Office, Washington, D. C. 206 pp.

1944. The Wolves of Mount McKinley. National Parks Fauna Series No. 5, U. S. Gov. Printing Office, Washington, D. C. 238 pp.

NAS-NRC.

1964. Nutrient Requirements of Domestic Animals. No. V. Nutrient Requirements of Sheep. Nationa1 Academy of Sciences - National Research Council. Publ. 1193. 40 pp.

Nelson, M.

1966. Problems of Recreational Use of Game Refuges. Trans. Desert Bighorn Council. p. 13-20.

Nichols, Lyman.

1974. Sheep Report - Dall Sheep Winter Range and Climate. Alaska Department of Fish and Game. Progress Report Project W-6.7R.

32 pp.

Oldemeyer, J. C., W. T. Barmore, and D. C. Gilbert.

1971. Winter Ecology of Bighorn Sheep in Yellowstone National Park. J. Wildl. Mgmt. 35(2):257-269.

Pallister, G. L.

1974. The Seasonal Distribution and Range Use of Bighorn Sheep in The Beartooth Mountains, With Special Reference to the West Rosebud and Stillwater Herds. Fed. Aid Job Prog. Rpt., Proj. W-120-R-5, Study No. 85.01, Job No. BG-8.03, Mont. Fish and Game Dept., 67 pp.

Pendergast, B. A.

1977. Mountain Goats and Coal Extraction in Northeastern British Columbia. in: Abstracts of the First Int. Mountain Goat Symp., Kalispe11, Montana.

Rath, Mike.

1977. Personal Communication, BLM Boise District, Idaho.

Robinson, D. J. 1965. Winter Feeding - A Blind Alley in Game Management. British Columbia Fish and Game Branch, 3 pp., mimeo. 
○

○

○ 
Romero, Miriam A.

1975. Comments on Burro Information Analysis. Trans. Desert Bighorn Council. p. 58-60.

Russo, J. P.

1957. Seasonal Water Requirements. Trans. Desert Bighorn Council. p. 64 .

Rutherford, W. H.

1972. Status of Transplanted Bighorn Sheep in Colorado. Game Information Leaflet No. 92. Colorado Dept. of Natural Resources, Div. of Game, Fish, and Parks. 3 pp.

1972b. Guidelines for Evaluation of Mountain Goat Transplant Sites in Colorado. Game Information Leaflet No. 91. Colorado Dept. of Natura1 Resources, Div. of Game, Fish, and Parks. 4 pp.

Rutherford, W. H., and R. L. Schmidt.

1973. Techniques for Supplementing Diet, Attracting and Baiting Bighorn Sheep. Game Information Leaflet No. 95. Colorado Div. of Game, Fish, and Parks, Denver. 3 pp.

Sands, Alan R.

1976. Evaluation of Potential California Bighorn Sheep Habitat, Jackson Mountains, Nevada. M. S. Thesis. Humboldt State Univ., Arcata, California. 104 pp.

Schallenberger, A. D.

1966. Food Habits, Range Use, and Interspecific Relationships of Bighorn Sheep in the Sun River Area, West-Central, Montana.

M. S. Thesis. Montana State Univ., Bozeman. 44 pp.

Smith, D. R.

1954. The Bighorn Sheep in Idaho, Its Status, Life History, and Management. Wild1. Bull. No. 1. Idaho Dept. of Fish and Game. 154 pp.

Sneva, Forrest A.

1976. Investigations on Oregon Deer Winter Range. Squaw Butte Experimental Sta. Progress Report. Oregon Agricultural Exp.

Station No. 321.

Spalding, D. J. and J. N. Bone.

1969. The California Bighorn Sheep of the South Okanagan Valley, British Columbia. British Columbia Dept. of Rec. and Cons., Fish and Wildl. Branch. 45 pp. 
○

○

○ 
Spalding, D. G., and H. B. Mitchell.

1970. Abundance and Distribution of California Bighorn Sheep in North America. Journal Wildl. Mgt. 34(2):473-475.

Stelfox, J. G.

1976. Range Ecology of Rocky Mountain Bighorn Sheep in Canadian National Parks. Canadian Wildl. Ser. 39.50 pp.

Streeter, Robert G.

1970. A Literature Review on Bighorn Sheep Population Dynamics. Spec. Report No. 24. Colorado Div. of Game, Fish, and Parks.

$11 \mathrm{pp}$.

Sugden, L. G. 1961. The California Bighorn in British Columbia. British Columbia Dept. Recreation and Conservation, Victoria. 58 pp.

Thomas J. W.

1977. Personal Communication. U. S. Forest Service. Range and Wildl. Habitat Lab. LaGrande, Oregon.

Thorne, Tom.

1977. Personal Communication. Wyoming Dept. of Game and Fish, Laramie, Wyoming.

Todd, Jeffrey $W$.

1972. A Literature Review on Bighorn Sheep Food Habits. Spec. Report No. 27. Colorado Div. of Game, Fish, and Parks. 21 pp.

Trefethen, James B. (Editor)

1975. The Wild Sheep in Modern North America. Winchester Press. New York. 302 pp.

Van Dyke, Walt.

1977. Personal Communication, Oregon State University, Corvallis, Oregon.

Vaughan, M. R.

1975. Aspects of Mountain Goat Ecology, Wallowa Mountains, Oregon.

M. S. Thesis. Oregon State University, Corvallis. 113 pp.

Verme, L. J., and D. E. U1lrey.

1972. Feeding and Nutrition of Deer. p. 275-291. in: Digestive Physiology and Nutrition of Ruminants. Vol. 3. Dept. Animal Science, Oregon State Univ., Corvallis. 350 pp. 
○

○

0 
Weaver, R. A., J. L. Mensch, and W. V. Fait.

1968. A Survey of the California Desert Bighorn (Ovis canadensis nelsoni) in San Diego County. Fed. Aid Job Prog. Rpt., Proj. W-51-R-13, Work Plan No. 1, Job No. 6A, Calif. Dept. of Fish and Game, 21 pp.

Weaver, R. A.

1972. California Bighorn in the Sierra Nevada Mountain Range. Wildl. Mgt. Admin. Rpt. No. 72-7. Calif. Dept. of Fish and Game. 16 pp.

1977. Personal Communication, California Dept. of Fish and Game, Sacramento, Calif.

Welles, E., and F. B. Welles.

1961. The Bighom of Death Valley. National Parks Fauna Series No. 6.242 pp.

Welsh, George W.

1971. What's Happening to Our Sheep. Trans. Desert Bighorn Council. p. 63-68.

Wilson, Lanny 0 .

1968. Distribution and Ecology of the Desert Bighorn in Southeast

Utah. Utah Div. Fish and Game. Publ. No. 68-5. 220 pp.

1969. The Forgotten Desert Bighorn Habitat Requirement. Trans. Desert Bighorn Council, p. 108-113.

1971. The Effect of Free Water on Desert Bighorn Home Range.

Trans. Desert Bighorn Council, p. 82-89.

1974. The Need for Genetic Research in Desert Bighorn Sheep.

Trans. Desert Bighorn Council. p. 50-52.

1977. Personal Communication. Boise, Idaho.

Wilson, Lanny 0., Jerry Day, Jack Helvie, Gerald Gates, Tomny L. Hailey, and George K. Tsukamoto.

1973. Guidelines for Re-Establishing and Capturing Desert Bighorns.

Trans. Desert Bighorn Council. p. 137-154.

Wishart, William.

1977. Personal Communication, Alberta Dept. of Fish and Wildlife, Edmonton, Alberta, Canada. 
0

○

0 
Woodgerd, W.

1964. Population Dynamics of Bighorn Sheep on Wildhorse Island. J. Wildl. Mgmt. 28(2):381-391.

Yoakum, Jim.

1964. Bighorn Food Habit-Range Relationships in the Silver Peak

Range, Nevada. Trans. Desert Bighorn Council. p. 95-102.

1966. Comparison of Mule Deer and Desert Bighorn Seasonal Food Habits. Trans. Desert Bighorn Council. p. 65-70.

1971. Habitat Management for the Desert Bighorn. Proc. of First North Amer. Wild Sheep Conf. p. 158-164.

1976. Biases in Bighorn Research Relating to Food Preferences and Determining Competition Between Bighorn and Other Herbivores.

Trans. Desert Bighorn Council. p. 46-48. 
○

0

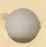

